\title{
OVERCOMING OBSTACLES TO RELIGIOUS EXERCISE IN K-12 EDUCATION
}

\author{
Lewis M. Wasserman
}

\section{INTRODUCTION}

Judicial decisions rendered during the last half-century have overwhelmingly favored educational agencies over claims by parents seeking religious accommodations to public education requirements, no matter what constitutional or statutory rights were pressed at the tribunal, or when the conflict arose.

Although these claim failures on the constitutional front are noteworthy in themselves, they are especially striking in the wake of the Religious Freedom Restoration Acts (RFRAs) passed by Congress in 1993 and thereafter by at least eighteen state legislatures, starting in $1993,{ }^{1}$ since these statutes were intended to insulate religious adherents from injuries previously inflicted by the courts. ${ }^{2}$

This article argues that these religious liberty statutes have failed to achieve their purpose in educational settings because legislators: (1) incorporated legal standards into the RFRAs which had previously failed to protect religious liberty and therefore doomed the laws' effectiveness from the start; (2) passed statutes of general application without specifically targeting religious freedom in education to ensure agencies acted in a manner which was consistent with the legislatures' intentions; (3) did not consider specific activities which were more likely than others to result in conflict with persons wishing to exercise religious freedom, and which activities educators could readily accommodate; (4) did not distinguish state interests which merely served a governmental purpose, from those which were essential to fulfilling educational agencies' core functions; and (5) focused on legal technicalities such as "substantial burdens" on religion and the "compelling state interest test," which are largely bereft of meaning outside of a particular agency's interests.

These deficiencies have made it difficult for judges to apply religious freedom

*Lewis M. Wasserman, J.D., Ph.D., Associate Professor, Educational Leadership and Policy Studies, University of Texas at Arlington. Special thanks to Pamela L. Steen, Esq., Member of the New York Bar, and the editors at the Journal of Legislation, for their thoughtful comments, which significantly improved the manuscript.

1. See Christopher C. Lund, Religious Liberty After Gonzales: A Look at State RFRAs, 55 S.D. L. REV. 466, 475-76 (2010); Caroline M. Corbin, Animus and the Kansas Preservation of Religious Freedom Act, JURIST-FORUM (Apr. 23, 2012), http://jurist.org/forum/2012/04caroline-corbin-religious-freedom.php;,Don Byrd, KY Legislature Overrides Governor's Veto of Religious Freedom Bill, Baptist Joint Committee for Religious Liberty (Mar. 28, 2013), bjcmobile.org/ky-legislature-overrides-governors-veto-of religiousfreedom-bill/.

2. JOHN WITtE, JR. \& JoEl A. NiChOLS, RELIGION AND THE AMERICAN CONSTITUTIONAL EXPERIMENT 160-161 (3d ed. 2011) (Professors Witte and Nichols use the phrase "age of statutes" to describe the current period in Free Exercise jurisprudence. They observe that "[s]ince the early 1980 s Congress and state legislatures have passed aggressive new statutes to offset the [Supreme] Court's narrowing of free exercise protections."). 
legislation to specific cases emanating from educational agencies, to predict when a religious burden falls within the reach of a statute, and to determine when the governmental interest overcomes that burden. Moreover, they have effectively ceded to the courts, power which enables jurists to "fill in the blanks" with their policy preferences. The goal of this article is to overcome these obstacles and offer guidance on legislation which protects religious liberty within Establishment Clause limits, while allowing educational agencies to perform their core functions. ${ }^{3}$

In contrast to other areas of political conflict, the RFRA was supported by "one of the broadest coalitions in recent political history, including Christians, Jews, Muslims, Sikhs, Humanists, and secular civil liberties organizations."4 Moreover, coalition members came from the political left as well as the right. ${ }^{5}$ These voices were, however, hardly uniform across the political spectrum. Contrary views appeared from conservatives concerned that accommodations stimulate judicial activism and may be anti-democratic, ${ }^{6}$ and from strict separationist liberals concerned that religious adherents receive special preferences over other groups. ${ }^{7}$ What is perhaps unique in the pro-accommodation ranks is the blending of interests which usually tend to conflict with one another in other areas of politics. ${ }^{8}$

The high water mark for religious liberty occurred when the Supreme Court decided Sherbert $v$. Verner ${ }^{9}$ in 1963. In Sherbert the Court expressly held for the first time that strict scrutiny should be used in evaluating laws burdening free exercise of religion, and declared unconstitutional the denial of unemployment benefits to a woman who was discharged from her job rather than work on her Saturday Sabbath. ${ }^{10}$

In 1990 the Supreme Court jettisoned the Sherbert standard in Employment Division v. Smith, by holding that laws interfering with religious exercise would face low-level rational basis scrutiny, at least when they were neutral and generally applicable, and did not target religious exercise for burdening, or were motivated by a desire to obstruct religion. ${ }^{11}$

The reaction to Smith was immediate and mostly negative, ${ }^{12}$ resulting in the

3. This article uses the term "accommodations" rather than "exemptions." The term accommodations captures more adequately the range of adjustments educational agencies might make to requests from religious adherents, whereas the term exemption implies a total excusal from an activity or requirement. Exemption is used when the relief is total or the term was used by the court whose decision is being discussed.

4. See Douglas Laycock \& Oliver S. Thomas, Interpreting the Religious Freedom Restoration Act, 73 TEX. L. REV. 209, 210 (1994).

5. Id. at 210-11.

6. See, e.g., Lino A. Graglia, Church of the Lukumi Babalu Aye: Of Animal Sacrifice and Religious Persecution, 85 GEO. L.J. 1 (1996). (1996).

7. See, e.g., Suzanna Sherry, Enlightening the Religion Clauses, 7 J. CONTEMP. LEGAL IsSUES 473

8. See, e.g., Laycock supra note 4, at 210-11, (listing members of the political coalition which supported the RFRA).

9. See 374 U.S. 398 (1963); see also discussion infra notes 28-60 and accompanying text.

10. Sherbert, 374 U.S. at $406,409-10$.

11. See 494 U.S. 872 (1990).

12. See, e.g., Michael W. McConnell, Free Exercise Revisionism and the Smith Decision, 57 U. CHI. L. REV. 1109, 1111 (1990); Douglas Laycock, The Remnants of Free Exercise, 1990 SUP. CT. REV. 1 (1990); but see, Gerard V. Bradley, Beguiled: Free Exercise Exemptions and the Siren Song of Liberalism, 20 HOFSTRA L. REV. 245, 245-47 (1991); Marci A. Hamilton, Religious Institutions, the No-Harm Doctrine and the Public 
RFRAs. The RFRAs were intended to bring Free Exercise protection back to what legislators considered the pre-Smith halcyon days, by incorporating the Sherbert standards into that legislation. This legislative retrospective on religious liberty under Sherbert was not only rose-colored, but grossly inaccurate. Indeed, as this article will show, the facts on the ground during the post-Sherbert, pre-Smith era were quite different than these legislators seem to have believed. ${ }^{13}$

\section{FREE EXERCISE FOUNDATIONS}

\section{A. Pre-Smith Jurisprudence}

In Sherbert $v$. Verner, ${ }^{14}$ mentioned earlier, a State denied unemployment benefits to a woman, a member of the Seventh-day Adventist Church, who quit her job rather than work on her Sabbath. The statute in issue required the worker to be available for work on Monday through Saturday, but did not expressly require anyone to work on Saturdays. ${ }^{15}$ The Court framed the issue as: "whether some compelling state interest enforced in the eligibility provisions of the ... statute justifies the substantial infringement of appellant's First Amendment right."16 The Court found the State failed to meet that burden, and held that the unemployment compensation board's denial of benefits violated the Free Exercise Clause. ${ }^{17}$

Although the law in Sherbert did not directly prohibit or regulate religiously motivated conduct, it certainly made it more difficult for Sherbert and others who deemed Saturday or Friday sacred and preserved for rest and worship. ${ }^{18}$ Indeed, the Court stated: ". . . to condition the availability of benefits upon this appellant's willingness to violate a cardinal principle of her religious faith effectively penalizes the free exercise of her constitutional liberties." 19 Further, the Court stated that the State's statutory scheme expressly "saves the Sunday worshipper from having to make the kind of choice which we here hold infringes the Sabbatarian's religious

Good, 2004 BYU L. REV. 1099, 1100 (2004).

13. See, e.g., James E. Ryan, Smith and the Religious Freedom Restoration Act: An Iconoclastic Assessment, 78 VA. L. REV. 1407, 1416-17, 1445-49 (1992) (discussing pre-Smith claim failures seeking religious exemptions).

14. 374 U.S. 398 (1963).

15. Id. at $400-01$.

16. Id. at 406 (Judge Richard Posner has characterized Sherbert as requiring "a comparison of two burdens: the burden on the person who is seeking a governmental benefit or being denied the benefit as the price of observing his religion, and the burden on the government of extending the benefit to someone who fails to meet the usual requirements for eligibility [citation omitted]. The more valuable the benefit to the claimant and hence the greater the burden on him of foregoing it in order to continue to observe his religion, the greater must be the burden on the government of relaxing the conditions it places on that benefit for a refusal to make an exception for the claimant to survive a challenge based on the First Amendment. Free Exercise of religion does not mean costless exercise of religion, but the state may not make the exercise of religion unreasonably costly." Menora v. Illinois High Sch. Ass'n, 683 F.2d 1030, 1033 (7th Cir. 1982).

17. Sherbert, 374 U.S. at $409-410$ (Sherbert requires strict scrutiny over state activity in such circumstances; therefore, a statute falling within its rule must be narrowly tailored to achieve that compelling governmental objective); see, e.g., Thomas v. Review Bd., 450 U.S. 707, 718 (1981).

18. Sherbert, 374 U.S. at 404.

19. Id. at 406 . 
liberty," 20 since it exempted the conscientious Sunday worshiper from the kind of refusal to which the appellant was subjected. This, concluded the Court, compounded the appellant's disqualification by the "religious discrimination" which the statutory scheme necessarily effected. ${ }^{21}$

The firmness of Sherbert's language appeared to be a boon to religious liberty. However, the reality turned out to be quite different. Other than unemployment compensation disputes involving religious accommodations in the workplace, ${ }^{22}$ the only other case decided between 1963 and 1990 where the Supreme Court found a Free Exercise violation was Wisconsin v. Yoder. ${ }^{23}$ Yet Yoder, like Sherbert before it, became a blueprint for unfulfilled promises. ${ }^{24}$

In Wisconsin v. Yoder, ${ }^{25}$ the Supreme Court examined whether Amish parents had a Free Exercise right to an exemption from Wisconsin's compulsory school laws for their fourteen and fifteen year old children. ${ }^{26}$ In extensively examining the Amish sect's unique history, the Court said:

Aided by ... three centuries as an identifiable religious sect and a long history as a successful and self-sufficient segment of American society, the Amish ... have convincingly demonstrated the sincerity of their religious beliefs, the interrelationship of belief with their mode of life, the vital role that belief and daily conduct play in the continued survival of Old Order Amish communities and their religious organization, and the hazards presented by the State's enforcement of a statute generally valid as to others. ${ }^{27}$

The Yoder court further observed the central place that home-vocational education played in Amish belief and practice, how that education was implemented to prepare the children for life within the Amish community, and the success this had produced over the centuries. ${ }^{28}$

On these facts, the Yoder Court held that "when the interests of parenthood are combined with a free exercise claim of the nature revealed by this record, more than merely a 'reasonable relation to some purpose within the competency of the State' is required to sustain the validity of the State's requirement under the First

20. Id.

21. Id.

22. See, e.g., Thomas v. Review Bd., 450 U.S. 707, 718 (1981); Hobbie v. Unemployment Appeals Comm'n of Florida, 480 U.S. 136 (1987); Frazee v. Illinois Dep't of Emp't Income Sec., 489 U.S. 829, 83435 (1989).

23. 406 U.S. 205 (1972).

24. See discussion infra Part VI (this article supports this assertion by examining the outcomes of all reported United States Courts of Appeals cases in which parents sought from educational agencies religious accommodations from statutory or regulatory requirements).

25. 406 U.S. 205 (1972).

26. Id. at 207.

27. Id. at 235 (emphasis added). Under Amish teaching, participation in high school and higher education undermines their faith because it is at marked variance with Amish values and way of life. This includes the impermissible exposure to "worldly" influences. Id. at 210-11.

28. Id. at 218. Indeed, the Court noted the absence of evidence that those Amish who left the community, with "their valuable vocational skills and habits," would become burdens on society. Id. at 225. 
Amendment. ${ }^{, 29}$ The Court concluded the State had failed to meet its burden. ${ }^{30}$ The Yoder Court took pains to limit its holding to the claim revealed in the record, "one that probably few other religious groups or sects could make."31

The threat to the Amish community's way of life posed by a compulsory school attendance statute was central to the holding in Yoder. ${ }^{32}$ While acknowledging that "religiously grounded conduct must often be subject to the broad police power of the State,"33 the Yoder Court, relying on, among other precedents, Sherbert $v$. Verner, concluded that "there are areas of conduct protected by the Free Exercise Clause of the First Amendment and thus beyond the power of the State to control, even under regulations of general applicability." 34 The Yoder Court stressed that when fundamental religious liberty is at stake, even the State's claim of a compelling interest in enforcing compulsory education laws requires a "searching" examination of "the interests that the State seeks to promote by its requirement for compulsory education to age 16 , and the impediment to those objectives that would flow from recognizing the claimed Amish exemption." 35

Thus, Yoder, applying Sherbert balancing, weighed the State's interest in universal education against the fundamental rights of Free Exercise and the traditional interest of parents in the religious upbringing of their children. ${ }^{36}$ Nevertheless, the Yoder Court emphasized Free Exercise of religion as the ground for its decision. ${ }^{37}$ Still, Yoder leaves us scratching our heads, since the Court did not advise us what weight to assign to the two constitutional claims it used to sustain the result, ${ }^{38}$ or what tools to employ when one such claim is asserted independently of the other.

There is dicta in Yoder which, from a contemporary perspective, leaves us further confused. The Yoder Court insisted that the constitutional right it protected did not extend to non-religious groups. ${ }^{39}$ Indeed, the Court indicated:

Thus, if the Amish asserted their claims because of their subjective evaluation and rejection of the contemporary secular values accepted by the majority, much as Thoreau rejected the social values of his time . . . their claims would not rest on a religious basis. Thoreau's choice was

29. Id. at 233 (emphasis added).

30. Id. at 236.

31. Id. at $235-36$.

32. Id.

33. Id. at 220 .

34. Id. (emphasis added).

35. Id. at 221 .

36. Id. at 213-15 (As to parents' due process right to control the upbringing of their child, the Yoder Court drew upon Pierce $v$. Society of the Sisters, which held that a compulsory education law requiring all children to attend public schools violates the Due Process clause (citing Pierce v. Society of the Sisters, 268 U.S. 510 (1925)).

37. Yoder, 406 U.S. at 236.

38. See id. at 213-14, 235-36.

39. Id. at 215 ("A way of life, however virtuous and admirable, may not be interposed as a barrier to reasonable state regulation of education if it is based on purely secular considerations; to have the protection of the Religion Clauses, the claims must be rooted in religious belief."). 
philosophical and personal rather than religious, and such belief does not rise to the commands of the Religion Clauses. ${ }^{40}$

Since Yoder eschewed protection to non-religious groups, and cast the Thoreaus of the world aside, ${ }^{41}$ it appears that groups unaffiliated with organized sects and individual acts of conscience are not protected by the Religion Clauses when pursuing educational accommodations. ${ }^{42}$

Given its theoretical cloudiness, Yoder may be fairly characterized as a resultsbased decision, tailored to a special situation. ${ }^{43}$ Moreover, Yoder's meaning today is perhaps more obscure than when it was decided some forty years ago. This is because of the Court's 1990 decision in Employment Division v. Smith. ${ }^{44}$ Although Smith treats Yoder as correctly decided, ${ }^{45}$ Smith did not resolve the ambiguities created by Yoder, as explained in the previous paragraphs, or indeed acknowledge they existed.

In Thomas $v$. Review Board of Indiana Employment Security Division, ${ }^{46}$ a Jehovah's Witness asked for a layoff from his manufacturing job and to receive unemployment benefits, after being transferred to a foundry that supplied military armaments, because the work violated his religious principles. ${ }^{47}$ The Indiana Supreme Court had called the choice a "personal philosophical" one, ${ }^{48}$ citing inconsistencies in the plaintiff's explanation of his beliefs, his practice of them, and the fact that other Jehovah's Witnesses testified that working on armaments was "scripturally acceptable." 49 The Supreme Court reversed, explaining that when a plaintiff draws a line, "it is not for [the Court] to say [it is] an unreasonable one."

Thomas made plain that "the guarantee of free exercise is not limited to beliefs which are shared by all of the members of a religious sect." 51 Thomas's special contribution to constitutional understanding comes from its recognition that "[i]ntrafaith differences . . are not uncommon among followers of a particular creed" and that "the judicial process is singularly ill equipped to resolve such differences ...." 52 This led the Thomas Court to withdraw from sorting heresy from mainstream doctrine within religious sects, ${ }^{53}$ in discharging its duty in constitutional

40. Id. at 216 .

41. Id. at $215-16$.

42. Id. at 216 .

43. See, e.g., Thomas C. Berg, State Religious Freedom Statutes in Private and Public Education, 32 U.C. DAviS L. REV. 531, 538 (1999) (suggesting that Yoder might require religious accommodations in educational settings, where the alternatives preferred by the State are more restrictive, and those proposed by adherents allow attainment of the State's goals). Professor Berg's reading of Yoder is similar to the one for which this article advocates, except that in light of Free Exercise developments at the Supreme Court, especially in Smith, this article argues for specific state statutory, rather than a federal constitutional, remedies. See infra Part VII,

44. 491 U.S. 872 (1990).

45. Id. at $881-82$ n.1.

46. 450 U.S. 707 (1981).

47. Id. at 710-11.

48. Id. at 714 .

49. Id. at 715 .

50. Id.

51. Id. at 715-16.

52. $I d$, at 715 .

53. Id. at 716 . 
interpretation. ${ }^{54}$ It stated: "Courts are not arbiters of scriptural interpretation." 55 Finally, Thomas makes clear that although courts may not impose rules of doctrinal conformity, claimed adherents still bear the burden of proving the honesty of their beliefs and how they apply to the accommodation they requested. ${ }^{56}$

\section{B. Employment Division v. Smith}

Smith involved a Free Exercise challenge by Native Americans to an Oregon statute which made it a felony to knowingly or intentionally possess peyote, a hallucinogenic substance. ${ }^{57}$ In Smith, employees of a private drug rehabilitation organization were fired because they ingested peyote for sacramental purposes at a ceremony of their Native American Church. ${ }^{58}$ The State of Oregon rejected their application for unemployment compensation, pursuant to a statute disqualifying employees discharged for work-related "misconduct." 59

In his majority opinion, joined by four of his colleagues, Justice Scalia rejected the employees' Free Exercise claim, declaring that the Free Exercise Clause did not require an exemption from an otherwise valid law. ${ }^{60}$ The Smith Court said that the Free Exercise Clause "does not relieve an individual of the obligation to comply with a valid and neutral law of general applicability on the ground that the law proscribes (or prescribes) conduct that his religion prescribes (or proscribes)."61 The Court stated: "We have never held that an individual's religious beliefs excuse him from compliance with an otherwise valid law prohibiting conduct that the State is free to regulate. On the contrary, the record of more than a century of our free exercise jurisprudence contradicts that proposition." 62 Smith made it plain that a law which

54. Id.

55. Id. The Court observed: "[R]eligious beliefs need not be acceptable, logical, consistent, or comprehensible to others in order to merit First Amendment protection." Id. at 714. The Supreme Court has adhered to its view in Thomas. See, e.g., Frazee v. Illinois Dep't of Income Sec., 489 U.S. 829, 834-35 (1989) (rejecting the State's argument that since applicant did not belong to an organized church, sect, or denomination, she was ineligible for a religious exemption entitling her to unemployment compensation benefits).

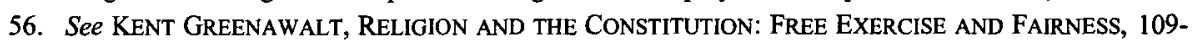
123 (2006) (supporting the legitimacy of judicial inquiries into sincerely felt versus fraudulent religious convictions on the one hand, while eschewing requirements for conformity of beliefs to doctrine within religious groups, on the other hand).

57. Emp't Div. v. Smith, 494 U.S. 872, 874 (1990).

58. Id. at 874 .

59. Id.

60. Id. at 879. Joining Justice Scalia in his majority opinion were Justices Rehnquist, White, Stevens and Kennedy. Justice O'Connor concurred in the Smith judgment, but argued instead that since the Oregon statute burdened religious exercise, strict scrutiny applied to this claim under Sherbert $v$. Verner and other precedents. Id. at 904. Applying strict scrutiny, she concluded that Oregon had a compelling state interest in preventing the use of peyote. Moreover, Justice O'Connor disagreed with the majority's description of its precedents and asserted: "The First Amendment was enacted precisely to protect the rights of those whose religious practices are not shared by the majority and may be viewed with hostility." Id. at 902 . For that reason "[t]he compelling interest test reflects the First Amendment's mandate of preserving religious liberty to the fullest extent possible in a pluralistic society." Id. at 903 .

61. Id. at 879 (citations omitted).

62. Id. at 878-79. Justice Blackmun wrote a dissenting opinion in which Justices Brennan and Marshall joined. The dissenters agreed with Justice O'Connor that the majority mischaracterized the precedents on which it relied. They asserted that strict scrutiny of laws which burden religion was required. See id. at 908-09. 
incidentally forbids (or requires) the performance of an act that one's religious belief requires (or forbids) is not unconstitutional, if the law is not specifically directed to religious practice and is otherwise constitutional as applied to those who engage in the specified act for nonreligious reasons. ${ }^{63}$

The Smith Court sharply criticized the use of Sherbert balancing, finding that a compelling government interest test, while useful in evaluating government distinctions based on race or government regulation over the content of speech, is inappropriate in the context of Free Exercise cases. The Court said: "What it produces in those other fields - equality of treatment and an unrestricted flow of contending speech-are constitutional norms; what it produces here-a private right to ignore generally applicable laws-is a constitutional anomaly."64

Justice Scalia commented:

Precisely because 'we are a cosmopolitan nation made up of people of almost every conceivable religious preference,' and precisely because we value and protect that religious divergence, we cannot afford the luxury of deeming presumptively invalid, as applied to the religious objector, every regulation of conduct that does not protect an interest of the highest order. $^{65}$

The Court concluded that in light of this country's religious diversity a compelling interest test applied to requests for exemption would "be courting anarchy.",66

Although the Smith Court recognized that its decision would dismay religious adherents, it predicted that society, through legislative enactments, would be

63. See id. at 879 .

64. Id at 886. The Court further explained: "To make an individual's obligation to obey such a law contingent upon the law's coincidence with his religious beliefs, except where the State's interest is 'compelling'-permitting him, by virtue of his beliefs, 'to become a law unto himself,'-contradicts both constitutional tradition and common sense." Id. at 885 (citation omitted). Moreover, the Court dismissed the argument that where the generally applicable regulation proscribes conduct which is essential to an individual's religion, strict scrutiny would then apply. Id. at 886-87. It asserted that the latter proposition would compel courts to determine the centrality of religious beliefs in Free Exercise cases ("What principle of law or logic can be brought to bear to contradict a believer's assertion that a particular act is 'central' to his personal faith?"). Id. at 887. Further, the Court contended that "[j]udging the centrality of different religious practices is akin to the unacceptable "business of evaluating the relative merits of differing religious claims"', a road down which it would not travel. Id. (citation omitted). The Tenth Circuit has construed Smith to mean that such claims are subject to only rational basis review, an eminently sound reading of Smith. See, e.g., Corder v. Lewis Palmer Sch. Dist., 566 F.3d 1219, 1232 (10th Cir. 2009).

65. Smith, 494 U.S. at 888 (citations omitted).

66. Id. at 888. The Court opined that use of a compelling interest test as the employees proposed "would open the prospect of constitutionally required religious exemptions from civic obligations of almost every conceivable kind-ranging from compulsory military service, to the payment of taxes, to health and safety regulation such as manslaughter and child neglect laws, compulsory vaccination laws, drug laws, and traffic laws, to social welfare legislation such as minimum wage laws, child labor laws, animal cruelty laws, environmental protection laws, and laws providing for equality of opportunity for the races. The First Amendment's protection of religious liberty does not require this." Id. at 888-89 (citations omitted). See Douglas Laycock, The Religious Exemption Debate, 11 RUTGERS J. L. \& RELIGION 140, 148 n.38 (2009) (Professor Laycock has characterized Justice Scalia's opinion as motivated by a fear of judicial activism and as casting his lot with the secular conservatives on this issue). 
"solicitous" of religious values. ${ }^{67}$ Notably, the Court was clear in declaring its preference for accommodationist legislative solutions to state-religion disputes, even when they were not mandated by the Free Exercise Clause. The Court stated:

But to say that a nondiscriminatory religious practice exemption is permitted, or even that it is desirable, is not to say that it is constitutionally required, and that the appropriate occasions for its creation can be discerned by the courts. It may fairly be said that leaving accommodation to the political process will place at a relative disadvantage those religious practices that are not widely engaged in; but that unavoidable consequence of democratic government must be preferred to a system in which each conscience is a law unto itself or in which judges weigh the social importance of all laws against the centrality of all religious beliefs. ${ }^{68}$

In 1993 the Supreme Court had an opportunity to apply Smith in Church of the Lukumi Babalu Aye v. Hialeah. ${ }^{69}$ In Lukumi the Court confronted a claim by Santeria religionists who use animal sacrifice as one of their principal forms of worship. ${ }^{70}$ After their killing, animals are cooked and eaten in accord with the Santeria's rituals. $^{71}$ Following the Santeria's announcement of plans to build a house of worship, school, cultural center, and a museum in Hialeah, Florida, the city adopted an ordinance prohibiting ritual sacrifice of animals. ${ }^{72}$ Under the ordinance "sacrifice" was defined as the killing of animals "not for the primary purpose of food consumption." slaughters, or sacrifices animals for any type of ritual, regardless of whether or not the flesh or blood of the animal is to be consumed."74

Justice Kennedy, writing for a unanimous court, held the law was unconstitutional. The Lukumi Court found that, contrary to Smith 's requirements, the law was not neutral, since its object was to prohibit a religious practice. ${ }^{75}$ It noted that the text of the law referred to "sacrifice" and "ritual" and the ordinance clearly targeted the Santeria religion. ${ }^{76}$ The Court focused on exceptions to the ordinance which permitted the killing of animals by other religions, such as the kosher slaughtering of animals, and other animal killing for nonreligious purposes. ${ }^{77}$ This selectivity in exemption from the ordinance manifested a lack of neutrality of the law. ${ }^{78}$ The Court also concluded the law was not one of "general applicability" within Smith's meaning. It stated that: “[d]espite the city's proffered interest in

\footnotetext{
67. Smith, 494 U.S. at 890 .

68. Id. at 890 (emphasis added).

69. 508 U.S. 520 (1993).

70. Id. at 524 .

71. Id. at 525 .

72. Id. at 525-26.

73. Id. at 527.

74. Id.

75. Id. at 533-34.

76. Id. at 535-36.

77. Id. at 536 .

78. Id. at $535-42$.
} 
preventing cruelty to animals, the ordinances are drafted with care to forbid few killings but those occasioned by religious sacrifice. Many types of animal deaths or kills for nonreligious reasons are either not prohibited or approved by express provision."79

Because the regulation was neither neutral nor of general applicability, as Smith required for less demanding scrutiny to apply, the Court examined the ordinance under strict scrutiny standards. ${ }^{80}$

\section{THE HYBRID THEORY OF RELIGIOUS INFRINGEMENT}

This Part examines the confounding language which appears in Smith concerning so-called hybrid claims. These claims tether Free Exercise to other claims, usually those related to due process, freedom of speech or association. Smith implied that "hybrid situations" which combine a Free Exercise claim with another colorable cause of action might merit a higher standard than the rational basis review announced in Smith. ${ }^{81}$ Despite Smith's seeming endorsement of hybrid rights the existence of such rights remains highly controversial. Justice Souter, for example, in his Church of the Lukumi concurrence criticized the hybrid rights theory as follows:

[T] he distinction Smith draws strikes me as ultimately untenable. If a hybrid claim is simply one in which another constitutional right is implicated, then the hybrid exception would probably be so vast as to swallow the Smith rule, and, indeed, the hybrid exception would cover the situation exemplified by Smith, since free speech and associational rights are certainly implicated in the peyote ritual. But if a hybrid claim is one in which a litigant would actually obtain an exemption from a formally neutral, generally applicable law under another constitutional provision, then there would have been no reason for the Court in what Smith calls the hybrid cases to have mentioned the Free Exercise Clause at all. ${ }^{82}$

79. Id. at 543 .

80. Id. at 546-47. Justice Scalia, in an opinion concurring in part and concurring in the judgment in which Chief Justice Rehnquist joined, wrote separately to argue that the purpose of the ordinance was not relevant to whether it was neutral or of general applicability. Id. at 558-59 (Scalia, J., concurring in part and concurring in judgment). Justice Souter also wrote separately, contending that the Court should reconsider and overrule Smith. Id. at 559-577 (Souter, J., concurring in part and concurring in the judgment). Justice Blackmun concurred in the judgment, in an opinion joined by Justice O'Connor, and "emphasize[d] that the First Amendment's protection of religion extends beyond those rare occasions on which the government explicitly targets religion (or a particular religion) for disfavored treatment." $I d$. at 577-78.

81. Id. at 233 (Smith's hybrid reference was rooted, in part, in that portion of the Court's decision in Wisconsin v. Yoder, 406 U.S. 205 (1972), which held that "when the interests of parenthood are combined with a free exercise claim of the nature revealed by this record, more than merely a 'reasonable relation to some purpose within the competency of the state is required to sustain the validity of the states' requirement under the First Amendment."')(internal citation omitted).

82. Church of the Lukumi Babalu Aye v. Hialeah, 508 U.S. 520, 657 (1993) (Souter, J., concurring). 
The First, ${ }^{83}$ Fifth, ${ }^{84}$ Eighth, ${ }^{85}$ and Tenth ${ }^{86}$ Circuit Courts of Appeals have read Smith to mandate application of stricter scrutiny to hybrid claims. That said, none of these Courts of Appeals has yet applied strict scrutiny to hybrid claims brought before them. The District of Columbia Circuit has recognized hybrid religious liberty claims, but to date has not adjudicated a case which it found fell into that category. ${ }^{87}$ The Fourth Circuit has not yet decided whether to recognize hybrid claims. ${ }^{88}$ The Seventh Circuit has not articulated its approach, but appears to approve of the Ninth Circuit's then current approach to hybrid claims. ${ }^{89}$ However, the Ninth Circuit has been somewhat inconsistent in that it appeared at first to recognize hybrid claims, ${ }^{90}$ but later appears to have rejected hybrid theory. ${ }^{91}$

83. See, e.g., Parker v. Hurley, 514 F.3d 87 (1st Cir. 2008) (refusing to decide parents' claim on Smith's hybrid theory, in light of ambiguities in its meaning and application, and instead treating the Due Process and Free Exercise claims separately and analyzing them interdependently [as the Court did in Wisconsin v. Yoder], on the ground that "the two sets of interests informed one another." Id. at 99), cert. denied, 555 U.S. 815 (2008); Gary S. v. Manchester Sch. Dist., 374 F.3d 15, $18-19$ (1st Cir. 2004) (citing Gary S. v. Manchester Sch. Dist., 241 F.Supp.2d 111, 121 (D.N.H. 2003) (recognizing hybrid claims, but requiring a plaintiff first to prove that the Free Exercise claim is joined with an independently viable companion right)), cert. denied, 543 U.S. 988 (2004); Brown v. Hot, Sexy and Safer Prods., Inc., 68 F.3d 525, 539 (1 st Cir. 1995) (although not explicitly recognizing the viability of hybrid theory, the court rejected the claim at bar because the "free exercise challenge [was] thus not conjoined with an independently protected constitutional protection."), cert. denied, 516 U.S. 1159 (1996).

84. See, e.g., Soc'y of Separationists v. Herman, 939 F.2d 1207, 1217 (5th Cir. 1991) (holding the claim, asserting that being forced to state an oath or affirmation violated freedom of religion and speech provisions, fell within the "religion-plus-speech" exception to Smith), rehearing en banc granted, 946 F.2d 1573, cert. denied, 506 U.S. 866 (1992).

85. See, e.g., Cornerstone Bible Church v. Hastings, 948 F.2d 464, 474 (8th Cir. 1991) (recognizing existence of hybrid-rights claims, although not defining the contours).

86. See, e.g., Axson-Flynn v. Johnson, 356 F.3d 1277, 1296-97 (10th Cir. 2004) (criticizing the approach taken by some courts which required that the claim joining the Free Exercise one be independently viable stating: "[I]t makes no sense to adopt a strict standard that essentially requires a successful companion claim because such a test would make the free exercise claim unnecessary[;] [i]f the plaintiff's additional constitutional claim is successful, he or she would typically not need the free exercise claim and the hybridrights exception would add nothing to the case."); Swanson v. Guthrie Indep. Sch. Dist., 135 F.3d 694, 699-700 (10th Cir. 1998) (concluding that since plaintiff has shown no colorable claim of infringement on the constitutional right to direct the upbringing of her children, it was not a hybrid rights case; a hybrid-rights plaintiff must show a fair probability or likelihood, but not certainty of success on the merits of the companion constitutional claim, and the claimant cannot "simply invoke the parental rights doctrine, combine it with a claimed free-exercise right, and thereby force the government to demonstrate the presence of a compelling state interest.").

87. See, e.g., Henderson v. Kennedy, 253 F.3d 12, 19 (D.C. Cir. 2001) (seemingly recognizing hybrid claims, but then rejecting claim made there on ground that "the combination of two untenable claims [cannot] equal[] a tenable one."), rehearing denied, 265 F.3d 1072, cert. denied, 535 U.S. 986 (2002); Equal Emp't Opportunity Comm'n v. Catholic Univ. of Am., 83 F.3d 455 (D.C. Cir. 1996) (concluding that Free Exercise, Establishment and RFRA independently protected the university from an employment discrimination claim, $i d$. at 470, but relying on Smith's hybrid theory as an alternative ground for supporting the decision. Id. at 467.).

88. See Workman v. Mingo Cnty. Bd. of Educ., 419 Fed. App'x 348, *353 (4th Cir. 2011) (noting split in circuits, but refusing to decide hybrid-rights claim, since even under strict scrutiny plaintiff's claim for excusal from immunization requirements would fail), cert. denied, 132 S.Ct. 590 (2011).

89. See Civil Liberties for Urban Believers v. Chicago, 342 F.3d 752, 765 (7th Cir. 2003) (quoting Miller v. Reed, 176 F.3d 1202, 1207-08 (9th Cir. 1999) (concluding that plaintiffs could not combine "utterly meritless" claims under a hybrid theory and obtain heightened scrutiny review).

90. See Miller v. Reed, 176 F.3d 1202, 1207-08 (9th Cir. 1999).

91. See Jacobs v. Clark Cnty. Sch. Dist., 526 F.3d 419, 440 n.45 (9th Cir. 2008) (rejecting plaintiffs' claims that their hybrid rights should be subject to strict scrutiny, noting the severe criticism the doctrine has 
In contrast to these circuits, the Sixth Circuit has explicitly rejected use of a more rigorous standard for hybrid claims in a case involving Free Exercise and various other First Amendment claims. ${ }^{92}$ The Sixth Circuit has characterized the hybrid approach as "completely illogical." regulation would violate the $[F]$ ree Exercise Clause if it implicates other constitutional rights but would not violate the Free Exercise Clause if it did not implicate other constitutional rights." 94 The Second Circuit, following the Sixth Circuit's lead, rejected a claim based on hybrid theory stating: "We too can think of no good reason for the standard of review to vary simply with the number of constitutional rights that the plaintiff asserts have been violated." 95 Moreover, the Second Circuit contended that since Smith involved a single Free Exercise claim, the Court's statements about hybrid actions were mere dicta. ${ }^{96}$ It stated: "[T]herefore, at least until the Supreme Court holds that legal standards under the Free Exercise Clause vary depending on whether other constitutional rights are implicated, we will not use a stricter legal standard to evaluate hybrid claims." ${ }^{, 97}$ The Third Circuit has also concluded that it will not employ a hybrid theory to resolve religious infringement claims. ${ }^{98}$ Accordingly, when the Second, Third and Sixth Circuits are faced with a neutral law of general applicability, they will decline to apply an elevated level of scrutiny to hybrid rights claims and instead apply Smith's rational basis standard. ${ }^{99}$

There is a strong case to make that the Second, Third and Sixth Circuits have gotten the better of the argument in the hybrid-claim debate. They have recognized that Smith was a single issue Free Exercise case and that Smith's statements about hybrid analysis were dicta. Moreover, Smith gives no guidance as to how to blend these multiple sources of right. For example, does the primary Free Exercise claim get more weight in the calculus of the blended hybrid claim? What does claim "interdependence" mean within the First Circuit's analysis? What does it mean that one claim "informs" the other?

Justice Souter made a cogent observation when he concluded that if a hybrid right is one which implicates another right the Smith rule would become meaningless. ${ }^{100}$ This is because virtually all Free Exercise claims implicate another

received and declining to be the first circuit to allow a plaintiff "to bootstrap a free exercise claim in this manner").

92. Watchtower Bible \& Tract Soc'y of New York, Inc. v. Stratton, 240 F.3d 553, 561-62 (6th Cir. 2001) (holding hybrid rights language in Smith is dicta), rev'd on other grounds, 536 U.S. 150 (2002); see also Kissinger v. Bd. of Trs. of the Ohio State Univ., Coll. of Veterinary Med., 5 F.3d 177, 180 (6th Cir. 1993).

93. See Kissinger, 5 F.3d at 177.

94. Id.

95. Leebaert v. Harrington, 332 F.3d 134, 144 (2d Cir. 2003).

96. Knight v. Conn. Dep't of Pub. Health, 275 F.3d 156, 167 (2d Cir. 2001).

97. Leebaert, 332 F.3 at 144 (quoting Kissinger, 5 F.3d at 180) (internal quotations omitted).

98. Combs v. Homer-Center Sch. Dist., 540 F.3d 231, 246-47 (3d Cir. 2008) (analyzing issue and concluding that until the Supreme Court says otherwise, it will treat hybrid-rights theory to be dicta).

99. See Leebaert, 332 F.3d at 144; Combs, 540 F.3d at 246-47; Kissinger, 5 F.3d at 180; Watchtower Bible \& Tract Soc'y of New York, Inc. v. Stratton, 240 F.3d at 560-62, rev'd on other grounds, 534 U.S. 971 (2002).

100. See discussion supra notes $128-138$ and accompanying text. 
right, whether it be First Amendment associational or speech on the one hand, or due process protections on the other hand, for example. Courts should discard hybridclaim analysis of religiously-based claims unless the Supreme Court directs otherwise; each constitutional right should be assessed on its individual merit. ${ }^{101}$

\section{SMITH'S INDIVIDUALIZED-EXEMPTION EXCEPTION}

This Part considers the individualized-exemption exception to Smith mentioned in Church of Lukumi, ${ }^{102}$ whereby a religious adherent may state an actionable Free Exercise claim against an agency when the agency makes available "individualized exemptions from a general requirement [but refuses] to extend that system to cases of religious hardship without a compelling reason."103

The Supreme Court has never explained what it meant in Church of Lukumi about a system of individualized exceptions which would trigger heightened scrutiny, and thereby impose a more searching review than Smith requires for neutral laws of general applicability. ${ }^{104}$ However, it appears that the facts in Sherbert $v$. Verner ${ }^{105}$ may exemplify a system of the kind to which the Court referred.

It will be recalled that in Sherbert the Court held that the denial of benefits violated the Free Exercise Clause because it "force[d] [Sherbert] to choose between following the precepts of her religion and forfeiting benefits, on the one hand, and abandoning one of the precepts of her religion in order to accept work, on the other hand." 106 Sherbert was denied unemployment benefits for failing to show "good cause" for her unemployment. In Sherbert, the good cause determination was made by an agency official who scrutinized an applicant's specific, personal circumstances, that is, on a case-by-case basis. Since this process invited exemptions on other than religious grounds, the State could not refuse to accept faith-based reasons on equal footing with secular reasons for awards of unemployment compensation. ${ }^{107}$ The inference to be drawn from such language is that where unfettered discretion resides in executive branch officials, opportunities for religious discrimination may arise and raise constitutional concerns.

The process of ad hoc basis exemptions used in Sherbert fits neatly into the construct of a system of individualized exemptions within the meaning of Smith and Lukumi. This exception to Smith seems to be limited to cases where the system's architecture is designed to uniformly require individualized determinations. Such systems are distinguishable from statutes which exempt whole categories of persons

101. For discussion about hybrid claims in the post-Smith era, see, e.g., Christopher C. Lund, A Matter of Constitutional Luck: The General Applicability Requirement in Free Exercise Jurisprudence, 26 HARV. J.L. \& PUB. POL'Y. 627, 631 (2003); Timothy J. Santoli, A Decade after Employment Division v. Smith: Examining How Courts Are Still Grappling with the Hybrid Rights Exception to the Free Exercise Clause of the First Amendment, 34 SUFFOLK U.L. REV. 649 (2001).

102. See discussion supra notes 115-127 and accompanying text.

103. Church of Lukumi, 508 U.S. at 537 (citing Smith, 494 U.S. at 884).

104. Id. at 537 (citing Smith, 494 U.S. at 884).

105. Sherbert v. Verner, 374 U.S. 398 (1963).

106. Id. at 404.

107. The Smith Court stated: "where the State has in place a system of individual exemptions, it may not refuse to extend that system to cases of "religious hardship' without compelling reason." 494 U.S. at 884. 
from rules of general applicability. For example, the Tenth Circuit has held that a home-schooled student's Free Exercise rights were not violated by a rule that enrollment in a public school's courses was limited to its full-time students, notwithstanding the fact that the rule contained limited exceptions for fifth year seniors and special education pupils. ${ }^{108}$ The key distinction is that the built-in exceptions were uniformly applied and did not entail individualized subjective determinations of the kind eschewed in Smith and Lukumi. ${ }^{109}$

A thoughtfully constructed state religious liberty statute for kindergarten through grade twelve ("K-12") education can help avoid the constitutional thicket resulting from the individualized-exemption exceptions. It would create "whole categories" to which exemptions apply and remove from education officials, broad discretionary authority concerning religious exemptions. This approach is taken in Part VII, infra, where the elements of a K-12 religious liberty statute are proposed. To inform that discussion the next part recites a brief history of the Religious Freedom Restoration Acts ("RFRAs") and suggests its implications for religion-based accommodations to public education requirements.

\section{THE RELIGIOUS FREEDOM RESTORATION ACTS}

\section{A. The Fate of Congressional Enactments in the Courts}

\section{The Religious Freedom Restoration Act}

The Smith Court's prediction in $\mathbf{1 9 9 0}$ about legislative activity in support of religious adherents ${ }^{110}$ was soon realized. Congress responded to Smith by enacting the Religious Freedom Restoration Act of 1993 (RFRA). ${ }^{11}$ RFRA declares that its purpose is "(1) to restore the compelling interest test as set forth in Sherbert v. Verner, ... . and Wisconsin v. Yoder, . . . and to guarantee its application in all cases where free exercise of religion is substantially burdened; and (2) to provide a claim or defense to persons whose religious exercise is substantially burdened by government." "12 The core of RFRA states:

Government shall not substantially burden a person's exercise of religion even if the burden results from a rule of general applicability, except . . . [g]overnment may substantially burden a person's exercise of religion only if it demonstrates that application of the burden to the person (1) is in

108. Swanson v. Guthrie Indep. Sch. Dist. No. I-L, 135 F.3d 694, 698-99, 701 (10th Cir. 1998).

109. Id. See also, Axton-Flynn v. Johnson, 356 F.3d 1277 (10th Cir. 2004) (holding that a Mormon college student who was refused an exemption in a classroom acting class when she refused to use profanity or take God's name in vain, raised sufficient questions of fact to warrant a trial on whether a system of individualized exemptions existed in the class, where other students were granted exemptions from course requirements on religious grounds and where plaintiff herself previously had been granted exemptions); but see, Hicks v. Halifax Cnty. Bd. of Educ., 93 F. Supp. 2d 649, 657 n.4 (E.D.N.C. 1999) (holding that a "limited financial hardship exception to the [school's] uniform policy does not rise to the level of a 'system of individualized exemptions"').

110. Emp't Div. v. Smith, 494 U.S. 872, 890 (1990).

111. Religious Freedom Restoration Act, 42 U.S.C.A. $\$ 2000$ bb et seq. (West 1993).

112. Id. 
furtherance of a compelling governmental interest; (2) is the least restrictive means of furthering that compelling governmental interest. ${ }^{113}$

A person whose religious practices are burdened in violation of RFRA "may assert that violation as a claim or defense in a judicial proceeding and obtain appropriate relief." 114

\section{City of Boerne v. Flores}

As originally enacted, RFRA applied to states as well as the federal government. In a 6-3 decision in City of Boerne v. Flores, ${ }^{115}$ the Supreme Court held the application of RFRA to states to be beyond Congress's legislative authority under $\S$ 5 of the Fourteenth Amendment, ${ }^{116}$ and declared the Act unconstitutional. ${ }^{117}$ In writing for the majority, Justice Kennedy explained that $\S 5$ empowers Congress to enact laws "to enforce" the amendment, but where Congress creates new constitutional rights or expands the scope of those rights, it cannot be acting to enforce that amendment. ${ }^{118}$ Thus, the Court held that under $\S 5$ Congress may act only to prevent or remedy a violation of rights recognized by the courts. Moreover, such laws must be narrowly tailored in that they must be proportionate and congruent to prevent or remedy the constitutional violations. ${ }^{119}$ RFRA failed to meet these requirements. ${ }^{120}$ Although City of Boerne thwarted Congress's efforts to limit the effects of Smith on state and local governments, it did not address the constitutionality of the RFRA as applied to the federal government. This is because $\S 5$, as the rest of the Fourteenth Amendment, does not apply to the federal government.

\section{The Federal RFRA and Public Education}

Despite City of Boerne's declaring RFRA unconstitutional in 1997 as applied to the states, decisions applying the RFRA are helpful in understanding the strengths and pitfalls of the Act's structure and language, and improving upon same where needed. This is especially true since state RFRAs are modeled on their federal counterpart.

In Cheema v. Thompson, ${ }^{121}$ the Ninth Circuit granted a preliminary injunction against a school district and ordered it to accommodate three Sikh children in their request to bring ceremonial knives to school. ${ }^{122} \mathrm{~A}$ central tenet of the students' religion required them to wear long hair, a comb, sacred underwear, a steel bracelet,

113. Id. $\S 2000 \mathrm{bb}-1$ (a) and (b).

114. Id. $\S 2000 \mathrm{bb}-1$ (c).

115. 521 U.S. 507 (1997).

116. Section 5 states: "Congress shall have the power to enforce, by appropriate legislation, the provisions of this article."

117. 521 U.S. at 512 .

118. Id. at 519-20.

119. Id. at 533-34.

120. Id. at 533-35.

121. 67 F.3d 883 (9th Cir. 1995).

122. Id. at 884,886 . 
and a ceremonial knife, known as a "kirpan."123 A kirpan's blade is made of steel and curved; the knife is about six to seven inches long, with a blade of about three and one-half inches long. ${ }^{124}$ Kirpans are worn in a sheath and held to the body with a leather strap. ${ }^{125}$

In its defense to the RFRA claim, the school district relied on its policy which banned all weapons, including knives, from school grounds, as well as two state statutes which made it a crime to carry a knife with a blade longer than two and onehalf inches on school property and authorized expulsion for possession of any knife of no reasonable use to the pupil on school property. ${ }^{126}$

In a prior appeal to the Ninth Circuit, that court had concluded that these Sikh children showed enough hardship to warrant a preliminary injunction based on irreparable injury, since they were excluded from school based on their religious practice. ${ }^{127}$ Moreover, in their prior appeal, the court agreed with the parents that the children's conduct was animated by a sincere religious belief, and the district's refusal to accommodate them put a substantial burden on their exercise of religion. ${ }^{128}$

In the prior appeal the circuit court also agreed that the school district had a compelling interest in campus safety and that the kirpan ban served that interest. ${ }^{129}$ However, because the school district had failed to develop evidence of whether less restrictive alternatives to a total ban existed, it remanded the case to the district court for further findings on this issue. On the remand the parties were unable to agree on an accommodation plan and the district court fashioned its own compromise and entered an order implementing its decision. ${ }^{130}$ The order allowed the children to return to school wearing the kirpan with a dull blade that was about three to three and one-half inches long with a total length of six and one-half to seven inches, including its sheath. ${ }^{131}$ The kirpan had to be sewn tightly to its sheath and worn on a strap so that it was not readily visible. ${ }^{132}$ A designated school official was permitted to make reasonable inspections to confirm these conditions were satisfied. ${ }^{133}$ In its review, the Ninth Circuit applied an abuse of discretion standard to the court's order and found no abuse. ${ }^{134}$

123. Id. at 884 .

124. Id. at n.1.

125. Id.

126. Id. at 886

127. Id. at 885 (citing Cheema v. Thompson, No. 94-16097, 1994 WL 477725 (Sept. 2, 1994) (memorandum disposition)).

128. Id.

129. Id.

130. Id. at 886 .

131. Id.

132. Id.

133. Id.

134. Id. Indeed, in what can only be characterized as an extremely critical view of the school district's conduct, the circuit court observed: "We note that defendants' own conduct left the district court with no thoughtful and careful advice as to how to accommodate student safety and yet respect the Sikhs' religious practices and beliefs." Id. at n.4. Though agreeing on the issue of a RFRA substantial burden, one judge on the panel dissented from the majority's holding that the school had failed to demonstrate a compelling interest. Id. at 889 (Wiggins, J., dissenting). 
In Battles v. Anne Arundel County Board of Education, ${ }^{135}$ a parent sought relief from educational requirements under the federal RFRA. ${ }^{136}$ The parent and child who engaged in home schooling claimed that Maryland's system of monitoring home education infringed on their right to free exercise of religion. ${ }^{137}$ The parent's choice to home-school her child stemmed from her belief that public schools indoctrinate children in atheistic or anti-Christian world views, promote paganism and evolutionism, and that the law's requirements for home schooling are designed to suppress parents' religion. ${ }^{138}$ Under Maryland's compulsory education law and home education requirements, parents were allowed to give home education to children, but the State retained a supervisory role. ${ }^{139}$ The State required the child to receive instruction in English, mathematics, science, social studies, art, music, health, and physical education. ${ }^{140}$ Moreover, the State required the parent to maintain a portfolio of instructional materials and examples of the child's work to show that the child is receiving regular and thorough instruction in those areas. ${ }^{141}$ The law directed the parent to permit a representative to observe the teaching given and review the portfolio at a mutually agreeable time and place, not more than three times a year. ${ }^{142}$ To ensure compliance with these regulations, a parent who educated her child at home was mandated to sign a consent form indicating that she had read and understood the regulations. ${ }^{143}$ Since Battles refused to sign the consent form, and would not allow the local school system to monitor her daughter's education, ${ }^{144}$ litigation ensued.

The court approached its analysis by incorporating into the RFRA the pre-Smith standard of review, as the Act required. It posed as a threshold question whether Battles' religious exercise was "substantially burdened." Citing to Sherbert $v$. Verner, ${ }^{145}$ the Battles court stated that: "a 'substantial burden exists in the Constitutional sense when governmental action compels a party to affirm a belief they do not hold, discriminates against an individual or group because of religious belief, inhibits the dissemination of particular religious views, or pressures a party to forego religious practice." 146

The Battles court found the parent and her child were not required to alter their religious beliefs, or forego acts necessary to comply with their beliefs, to satisfy Maryland's monitoring requirements for homeschooling, and school districts were not required to purge from their curriculum content which the parents found

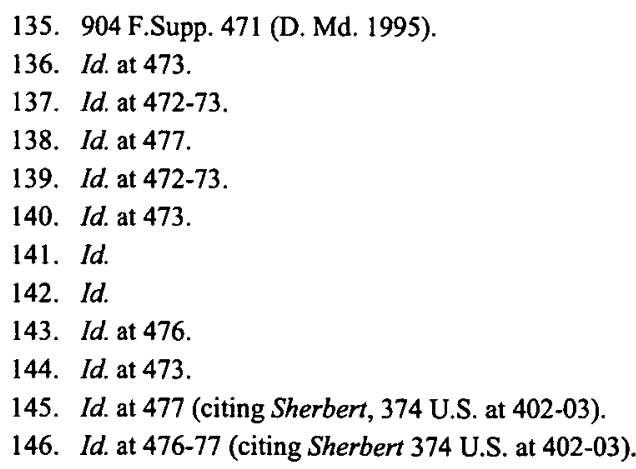


religiously objectionable. ${ }^{147}$ Accordingly, the court dismissed the RFRA complaint for the parent's failure to show a substantial religious burden without having to consider the State's interest in refusing the accommodation. ${ }^{148}$ The Battles court read the Sherbert test for a religious burden quite narrowly. Sherbert stated expressly that religious burdens, for purposes of Free Exercise analysis, included the indirect results of legislation. ${ }^{149}$ Under Thomas $v$. Review Board, ${ }^{150}$ decided about eighteen years after Sherbert and about fourteen years before Battles, the Supreme Court reiterated Sherbert's advice that a state-mandated affirmance or denial of a religious belief is not the only way that a religious adherent may establish a Free Exercise burden. ${ }^{151}$ Thomas reaffirmed Sherbert's teaching that a state cannot require a person to choose between the benefits of a public program and a religious belief. Since Battles complained that, among other things, the required curriculum diminished the importance of Christian holidays, inhibited the dissemination of particular religious views, or pressured her to forego religious practice, ${ }^{152}$ the legislation's effect was to impede the observance of one or more religious practices. ${ }^{153}$

Battles is a paradigmatic example of a court using a narrow definition of substantial burden to dismiss a case. Battles' religious convictions were apparently sincerely felt. Her articulated religious grounds for the exemption were concrete and comprehensible. Although Battles' accommodation request was broad-based and perhaps poorly articulated, aspects of it could readily be accommodated by narrow tailoring, without obstructing the State's interest in achieving its educational goals.

The State's requirement of school officials entering the Battles' home and observing the instruction, and its command that the parents maintain relatively detailed records, burdened the parent's religious exercise, when simply requiring the child to be tested on core curricular requirements at sensible intervals, like other children presumably were, should have satisfied the State's interest. Battles illustrates why broader and particularized statutory protections for religious rights are needed if the mistakes of the past are not to be repeated. These remedies are addressed in Part VII.

The court in Cheema $v$. Thompson, ${ }^{154}$ applied the federal RFRA as its drafters intended. However, it took two Ninth Circuit reviews in Cheema to reach the correct result, largely due to school officials' intransigence. Cheema is noteworthy in that it is one of the rare occasions where a religious adherent prevailed against an educational agency. Its exceptionality implies the legislators need to do more to secure the rights they intended to protect. The result in Battles v. Anne Arundel County Board of Education is far more typical in that it represents courts defeating cases on threshold issues like the existence of a religious burden, thereby avoiding a

147. Id. at 477 .

148. Id. at $477-78$.

149. Sherbert v. Verner, 374 U.S. 398, 403 (1963).

150. Thomas v. Review Bd of Ind. Emp't Sec. Div., 450 U.S. 707, 718 (1981).

151. Id.

152. Battles, 904 F.Supp. at 477.

153. See Sherbert v. Verner, 374 U.S. at 404.

154. See discussion supra notes 170-186 and accompanying text. 
determination of the compelling nature of the governmental interest. ${ }^{155}$

\section{Gonzales v. O Centro Espirita Beneficente Uniao Do Vegetal}

The question left open by City of Boerne as to RFRA's impact on the United States was largely resolved in 2006 in Gonzales v. O Centro Espirita Beneficente Uniao Do Vegetal. ${ }^{156}$ In Gonzales, a religious sect brought a suit in which it sought to preliminarily enjoin the United States from barring its use of a substance known as hoasca, a tea containing a hallucinogen, in religious ceremonies. ${ }^{157}$ The United States contended its authority for the ban derived from the Controlled Substances Act ("CSA"). ${ }^{158}$ There, the Supreme Court, applying the RFRA, held in a unanimous 80 vote that the government had the burden to show a compelling interest, and it failed to meet that burden in barring the sect's sacramental use of hoasca. ${ }^{159}$

The Gonzales Court rejected the government's argument that the CSA could not function properly if it was subjected to exceptions. ${ }^{160}$ The Court observed that RFRA and its strict scrutiny mandate required "an inquiry more focused than the Government's categorical approach" to CSA's prohibitions. ${ }^{161}$ In particular, the Court emphasized that the RFRA's compelling interest test required examining the application of the challenged law to the person, that is, the particular claimant whose sincere exercise of religion is being substantially burdened. ${ }^{162}$ The Court explained that Sherbert's and Yoder's standards were expressly incorporated into RFRA. ${ }^{163}$ This required the Court to look beyond broadly formulated governmental interests in justifying across-the-board burdens placed on religious exercises and the harms done to the adherents. ${ }^{164}$ The Court noted that hoasca's listing in CSA as a forbidden substance did not relieve the government of its obligation to satisfy RFRA requirements. ${ }^{165}$ It observed that CSA itself authorized "the Attorney General to 'waive the requirement for registration of certain manufacturers, distributors, or dispensers if he finds it consistent with the public health and safety," "166 suggesting that Congress's findings with respect to CSA's Schedule I substances "should not carry the determinative weight." 167 Moreover, the Court observed that Congress had decreed an exception from CSA for the religious use of peyote by Native Americans. ${ }^{168}$ Since Congress permitted such use by "hundreds of thousands of Native Americans practicing their faith," such findings tended to undermine the

155. See discussion supra notes 154-178 and accompanying text.

156. 546 U.S. 418 (2006).

157. Id. at 423 .

158. Id. See Controlled Substances Act, 21 U.S.C. $\$ 810$ et seq. (West 2000).

159. Gonzales, 546 U.S. at $422-23$.

160. Id. at 430.

161. Id.

162. Id. at $430-31$ (internal quotation marks omitted).

163. Id. at 431 .

164. Id.

165. Id. at 432

166. Id. (internal citation omitted).

167. Id. at 432-33.

168. Id. at 433 . 
government's contention that a similar exception could not apply in this case. ${ }^{169}$ Notably, the Gonzales Court referred to the then recent decision in Church of Lukumi as establishing that under its strict scrutiny jurisprudence "a law cannot be regarded as protecting an interest 'of the highest order'. . .when it leaves appreciable damage to that supposedly vital [governmental] interest unprohibited."170 Moreover, the Court's reading of RFRA made clear that Congress conferred on the courts the obligation "to consider whether exceptions are required under the test set forth by Congress." 171

Importantly, Gonzales should not be interpreted too broadly. Its reach includes protection from federal laws only. Since most state-religion disputes arise in local venues, and certainly K-12 educational disputes are quintessentially local, its impact on educational practice should be minimal. Nevertheless, Gonzales's construction of the RFRA, particularly as to its criteria for satisfying narrow tailoring requirements, should be helpful when designing state religious freedom statutes.

\section{Religious Land Use and Institutionalized Persons Act ("RLUIPA")}

The Supreme Court's City of Boerne decision ${ }^{172}$ led to another Congressional effort under the title Religious Land Use and Institutionalized Persons Act of 2000 ("RLUIPA"). ${ }^{173}$ RLUIPA requires the government to meet strict scrutiny standards when it burdens religious exercise in two areas only: land use decisions ${ }^{174}$ and institutionalized persons. ${ }^{175}$ Congress grounded RLUIPA's land use provisions in the Commerce Clause, and its protection of institutionalized persons in the Spending Clause, as a condition of receipt of federal funds. ${ }^{176}$ Notably, the Act defines religious conduct to include "any exercise of religion, whether or not compelled by, or central to, a system of religious belief." 177

In 2005, the Supreme Court in Cutter v. Wilkinson rejected a prisoner's claim that the RLUIPA was facially unconstitutional under the Establishment Clause by favoring religion. ${ }^{178}$ In a unanimous decision, authored by Justice Ginsburg, the Cutter Court concluded that the government's accommodation of free exercise of religion under the Act, did not reach Establishment Clause limits. ${ }^{179}$ Notably, Cutter left open the question of whether RLUIPA exceeded congressional commerce or

169. Id.

170. Id. at 433 (quoting Church of Lukumi Babalu Aye, Inc. v. Hialeah, 508 U.S. 520, 547 (1993) quoting Florida Star v. B.J., 491 U.S. 524, 541 (1989)).

171. Id. at 434 .

172. See discussion supra notes $146-160$ and accompanying text.

173. Religious Land Use and Institutionalized Persons Act of 2000, 42 U.S.C. $\$ 2000 \mathrm{cc}$ (West 2000).

174. $I d$. at $\S 2000 \mathrm{cc}(\mathrm{a})(1)$.

175. Id. at $\S 2000 \mathrm{cc}-1(\mathrm{a})(1)-(2)$.

176. See id. $\S 2000 \mathrm{cc}-1(\mathrm{~b})(1)$ ("This section applies in any case in which ... the substantial burden is imposed in a program or activity that receives Federal financial assistance.").

177. Id. at $\S 2000 \mathrm{cc}-5(7)(\mathrm{A})$.

178. 544 U.S. 709, 719-20, 725 (2005). The Cutter Court stated expressly that it was not reviewing Section 2 of the RLUIPA which applied to land-use regulation. Id. at $716 \mathrm{n} .3$.

179. Id. at 719-24. 
spending powers. ${ }^{180}$ Cutter's Commerce Clause and Spending Power questions should not, however, pose any problems for the legislation proposed in Part VII, infra, since only state statutes are involved. That said, Cutter doubles down on Justice Scalia's open invitation for legislative action in Smith. ${ }^{181}$ Although Cutter leaves unanswered questions about the limits of federal power in protecting religious exercise through the Commerce and Spending Clauses, it appears that Congress still enjoys substantial power to legislate in this area.

\section{B. Current Constitutional Landscape}

Based on the previous discussion, the following conclusions may be drawn about the complex statutory and constitutional relationship involving governmental accommodations to religious exercise: (1) rational basis review under Smith will control First Amendment Free Exercise challenges to state laws of general applicability; (2) except under the RLUIPA, state actions which burden land use and institutionalized persons will not be required to meet strict scrutiny standards; (3) federal actions must satisfy strict scrutiny under the RFRA; ${ }^{182}$ (4) Congress is not precluded under Cutter from exercising its Article I Section 8 Tax and Spending powers to protect religious liberty in the states; (5) such legislation could lawfully condition the States' participation in federal programs on compliance with Free Exercise requirements, as defined in the law; (6) it is likely the Supreme Court would not consider such conditioned spending to encroach on state prerogatives, since states would enter into such agreements voluntarily with federal agencies. ${ }^{183}$ These conclusions suggest that Congress still enjoys significant power in protecting

180. See id. at 715 n.2; but see id. at. 732-33 (Thomas, J., concurring) (acknowledging the absence of a Spending Clause challenge in the case, but suggesting that the legislation "may well exceed the spending power."). For recent discussions of RLUIPA in land use cases, see generally, John Infranca, Institutional Free Exercise and Religious Land Use, 34 CARDOzo L. REV. 1693 (2013); Brian K. Mosley, Note, Zoning Religion Out of the Public Square: Constitutional Avoidance and Conflicting Interpretations of RLUIPA's Equal Terms Provision, 55 ARIZ. L. REV. 465 (2013).

181. See discussion supra notes 80-113 and accompanying text.

182. Invocation of strict scrutiny standards under the RFRA for actions taken by the federal government has produced mixed results. See, e.g., Allison M. Dussias, Friend, Foe, Frenemy: The United States and American Indian Religious Freedom, 90 DENV. U. L. REV. 347 (2012) (criticizing the post-Smith responses to Indian religious freedom where federal government officials make public land management-related decisions and the federal courts' handling of claims related to Indian religious freedom).

183. See generally South Dakota v. Dole, 483 U.S. 203 (1987). Dole created a four-part test to gauge the constitutionality of individual conditional grants. $I d$. at 207-08. First, the condition must further the general welfare, to which Congress's judgment in this regard receives substantial judicial deference. Id. at 207. Second, the condition must be clearly and unambiguously stated. Id. Third, the condition must be germane to the conditioned spending. Id. at 207-08. Fourth, there must be no "independent constitutional bar" to the condition. Id. at 208. That is, "the [spending power] may not be used to induce the States to engage in activities that would themselves be unconstitutional." Id. at 210 . In light of the Court's sustaining religious freedom legislation as against the United States in City of Boerne, and against the states in Cutter, it seems that despite some uncertainty, such legislation would survive attack from federal and state objectors. That said, the extent to which Congress exacted a price from the states for compliance with such legislation would play into the analysis. This is evident from the so-called Obama-care legislation where, for the first time, the Supreme Court held that Congress exceeded its Spending Clause powers by penalizing states for their refusal to participate in a newly enacted national health care program. See Nat'l Fed'n of Indep. Bus. v. Sebelius, 132 S.Ct. 2566, 260607 (2012) (holding that Congress failed to give the states a genuine choice whether to accept federal money because of the severe consequences to them by not doing so). 
religious exercise in the states, including actions by state educational agencies which burden such exercise.

Each of the fifty states has a constitution which, to varying degrees, touches upon religion. $^{184}$ These constitutions often contain more specific protection than the United States Constitution's Religion Clauses. ${ }^{185}$ Because they have sometimes been interpreted to expand on religious liberty, relative to their counterpart in the United States Constitution, state provisions have received increased scholarly attention in the post-Smith era. ${ }^{186}$ Since state constitutional provisions have rarely been applied to controversies involving religious accommodations from $\mathrm{K}-12$ requirements, they are excluded from the coverage of this article.

\section{State Religious Freedom Restoration Acts}

Professor Laycock has described church-state conflicts as perpetual, in which religionists must prevail in every battle, at each governmental level, if their liberty is to be preserved. ${ }^{187}$ Decisional outcomes in courts at every level of the judicial system certainly support this assertion. $^{188}$

184. See generally EDD DOERR \& ALBERT J. MENENDEZ, RELIGIOUS LIBERTY AND STATE CONSTITUTIONS (1993); Robert F. WILliams, The LAW OF AMERICAN STATE CONSTITUTIONS 113-230 (2009) (discussing interpretation of state constitutional rights in the context of a federalist system).

185. The state provisions fall into categories: "Acknowledgement of God Provisions" which "express gratitude to God, acknowledge God, or recognize humans as His creation;" "Religion Provisions" which contain "bills of rights that broadly declare the freedom of religion and address the relationship between church and state, those that prohibit the government from requiring those conscientiously opposed to bearing arms to serve in the militia, and those that prescribe oaths for government actors that invoke God's help;" "Education Provisions" which "prohibit the government from supporting any sectarian or denominational school with money raised for the public schools, and those that prohibit instruction on any sectarian or denominational doctrine in any public school;" and "Finance/Property Tax Provisions" which "includes those providing that property used for religious or charitable purposes may be exempted from property taxation and prohibiting the government from laying any tax or appropriating public money in aid of any church or private or sectarian school." LEWIS Roca RoTHGERBER, The Religious Liberty Archive,

http://www.churchstatelaw.com/stateconstitutions/index.asp (last visited on Apr. 8, 2012) (collecting states' constitutional provisions).

186. See, e.g., Piero A. Tozzi, Whither Free Exercise: Employment Division v. Smith and the Rebirth of State Constitutional Free Exercise Clause Jurisprudence?, 48 J. CATH. LEG. STUD. 269 (2009); Christine M. Durham, What Goes Around Comes Around: The New Relevancy of State Constitution Religion Clauses, 38 VAL. U. L. REV. 353 (2004); So Chun, Comment, A Decade After Smith: An Examination of the New York Court of Appeals' Stance on the Free Exercise of Religion in Relation to Minnesota, Washington, and California, 63 AlB. L. REV. 1305 (2000); Angela C. Carmella, State Constitutional Protection of Religious Exercise: An Emerging Post-Smith Jurisprudence, 1993 BYU L. REV. 275 (1993).

187. See Douglas Laycock, The Religious Freedom Restoration Act, 1993 BYU L. REV. 221,229 (1993) ("Churches have to win these battles over and over, at every level of government. They have to avoid being regulated by the Congress, by the state legislatures, by the county commissions, by the city councils, and by the administrative agencies at each of these levels. Churches have to avoid being regulated this year and next year and every year after that. If they lose even once in any forum, they have lost the war....").

188. See discussion infra notes 222-313 and accompanying text (addressing effectiveness of federal and state RFRAs); see also discussion infra Part VI (providing overview of Supreme Court and United States Courts of Appeal decisions in educational religious accommodation cases). 


\section{Overview of State RFRAs}

Sixteen states enacted mini-RFRAs through $2010 .^{189}$ In 2012, Kansas passed the Preservation of Religious Freedom Act (KPRFA). ${ }^{190}$ And in 2013, Kentucky was added to the list, when it enacted its version of the RFRA. ${ }^{191}$ Notably, major population centers like California, New York, Ohio, and Michigan have not adopted such measures. ${ }^{192}$

Although state RFRAs represent efforts to return religious liberty to pre-Smith levels under the Sherbert and Yoder tests, their standards for establishing religious burdens are not uniform. Among those which have passed mini-RFRAs, at least eleven require a showing of a "substantial burden" on religious exercise, ${ }^{193}$ two require a mere "burden," 194 and two mandate "restrictions on religious liberty,"195 before the state's interest is subject to strict scrutiny. Once the applicable burden is

189. See Lund, supra note 1, at 479. These states are: Arizona Religious Freedom Restoration Act, ARIZ. REV. STAT. ANN. $\$ \$ 41-1493-1493.02$ (2009); Connecticut Religious Freedom Restoration Act, CoNN. GEN. STAT. ANN. $\$ 52-571 \mathrm{~b}$ (West 2009); Florida Religious Freedom Restoration Act, FLA. STAT. ANN. \$§ 761.0105 (West 2010); Idaho Religious Freedom Act, IDAHO CODE ANN. \$§ 73-401-404 (West 2009); Illinois Religious Freedom Restoration Act, 775 ILL. COMP. STAT. ANN. 35/1 to /99 (West 2009); Missouri Religious Freedom Restoration Act, Mo. ANN. STAT. $\S \S 1.302-307$ (West 2010); New Mexico Religious Freedom Restoration Act, N.M. STAT. ANN. $\S \S 28-22-1$ to 28-22-5 (West 2006); Oklahoma Religious Freedom Act, OKLA. STAT. ANN. tit. 51, §§ 251-258 (West 2010); Pennsylvania Religious Freedom Protection Act, 71 PA. CONS. STAT. ANN. $\S \S 2401-2407$ (West 2009); Rhode Island Religious Freedom Restoration Act, R.I. GEN. LAWS ANN. $\S \S 42-80.1-1$ to -4 (West 2006); South Carolina Religious Freedom Act, S.C. CoDE ANN. \$§1-3210 to -60 (2010); Tennessee Religious Freedom Amendment, TENN. CODE ANN. \$ 4-21-1101 (2009); Texas Religious Freedom Restoration Act, TEX. CIV. PRAC. \& REM. CODE ANN. §§ 110.001-012 (Vernon 2009); Utah Religious Land Use Act, UTAH CODE ANN. $\S ~ 63 L-5-101$ to -403 (West 2008); Virginia Religious Freedom Restoration Act, VA. CODE ANN. $\S \S 57-1$ to 57-2.02 (West 2009). Alabama's state RFRA is embedded in its state constitution, which makes its repeal much more difficult. See ALA. CONST. art. I, $\S 3.01$; See Thomas C. Berg \& Frank Myers, The Alabama Religious Freedom Amendment: An Interpretative Guide, 31 CUMB. L. REV. 47, 56-58 (2001) (making this point). Utah's RFRA has been renamed the Utah Religious Land Use Act to conform more closely to the statute's purposes. See Utah Code § 63L-5-101 (2010).

190. 2012 Kan. Sess. Laws____ (enacting HB 2203). Under the Act, a "substantial burden" triggers the Act's requirements; it limits a govermmetal "compelling interest" to those "interests of the highest order." See id.; see also Caroline M. Corbin, Animus and the Kansas Preservation of Religious Freedom Act, JURISTFORUM (Apr. 23, 2012), http://jurist.org/forum/2012/04caroline-corbin-religious-freedom.php (observing the similarity of the Kansas act to other state RFRAs in that it subjects to strict scrutiny any law which imposes a substantial burden on religious practice, but that the law creates a special defense to municipal antidiscrimination ordinances where, for example, a land lord will not rent to same sex couples).

191. Kentucky Religious Freedom Act, 2013 Ky. Acts __ (enacting HB 279); see also Don Byrd, KY Legislature Overrides Governor's Veto of Religious Freedom Bill, Baptist Joint Committee for Religious Liberty (Mar. 28, 2013), bjcmobile.org/ky-legislature-overrides-governor-veto-of religious-freedom-bill/; Peter Smith, Religious- Liberty laws have had limited effect nationwide, THE COURIER-JourNAL (Mar. 19, 2013), blogs.courier-journal.com/faith/2013/03/19/religious-liberty-bill-is-no-slam-dunk-for-defiance/ (stating that the bill "creates the right for someone motivated by 'a sincerely held religious belief' not to be 'substantially burdened unless the government proves by clear and convincing evidence that it has a compelling governmental interest in infringing the specific act or refusal to act and has used the least restrictive means to further that interest." ).

192. See Lund, supra note 1 , at 479 . For example, Lund observes that more than one in six Americans lives in New York and California alone, where RFRA bills have failed. Id.

193. These are: Arizona, Florida, Idaho, Illinois, Oklahoma, Pennsylvania, South Carolina, Tennessee, Texas, Utah, and Virginia. Lund, supra note 1, at 477.

194. Connecticut and Alabama fall into this category. Id.

195. Rhode Island and Missouri have set this threshold for actionable claims. Id. 
established, all RFRA states expressly require the government to show that the burden furthers a compelling interest, and that the state has used the least restrictive means to further that interest. ${ }^{196}$

Variances exist among the mini-RFRAs in other respects. These include: whether money damages are available for violations of the Act, ${ }^{197}$ the availability of attorney fee awards to prevailing parties, ${ }^{198}$ and procedural obstacles, such as a notice of claim requirement as a condition precedent to suit. ${ }^{199}$ Moreover, state RFRAs vary in coverage exclusions. Exclusions are written into the statutes most often with respect to persons incarcerated in state prisons, but these are not the only coverage exclusions to mini-RFRAs. ${ }^{200}$

Commentators have uniformly observed that mini-RFRAs have failed to achieve their purpose in protecting religious liberty. Among the states that have enacted RFRAs, four have never decided a case under the Act, ${ }^{201}$ and another six have decided only one or two cases. ${ }^{202}$ The two most recent enactments in Kansas and Kentucky have not resulted in any reported cases. Moreover, in most jurisdictions with state RFRAs, plaintiffs have not won a single case and, in jurisdictions where victories occurred, they were indeed scarce. ${ }^{203}$ Of even greater concern is that courts have routinely, and improperly, raised the threshold for showing a "substantial burden" in state RFRA cases, thereby permitting courts to dismiss cases without having to apply strict scrutiny to the government conduct being challenged. ${ }^{204}$ And, where religious adherents' cases have initially survived, courts have typically applied rational basis review to the government's conduct, in essence refusing to follow the legislative command that it show a compelling interest. ${ }^{205}$ The great irony in all of this is that the purported goal of these state enactments was to counter the adverse effects of City of Boerne and replace them with more religion friendly Sherbert/Yoder or Gonzales style review.

196. See Lund, supra note 1, at 477-85. See also, e.g., Kansas Preservation of Religious Freedom Act, 2012 Kan. Sess. Laws ___ (enacting HB 2203); Kentucky Religious Freedom Act, 2013 Ky. Rev. Stat. Adv. Legis. Serv. (West) Acts (enacting HB 279).

197. The states which expressly permit the recovery of money damages are: New Mexico, Oklahoma, Rhode Island, Texas, see Lund, supra note 1, at 478 n.76, and Kansas, see Kansas Preservation of Religious Freedom Act, 2012 Sess. Laws ___ (enacting HB 2203). Two states forbid such recovery: Pennsylvania and Virginia. See Lund, supra note 1 , at 479 n. 77.

198. Lund, supra note 1, at 478 n.73 (listing Arizona, Florida, Idaho, Illinois, New Mexico, Oklahoma, South Carolina, Tennessee, Texas, and Virginia as states in which fees and costs may be recovered); see also, Kansas Preservation of Religious Freedom Act, 2012 Kan. Sess. Laws __ (allowing attorneys' fee awards). The federal RFRA allows such recoveries. See 42 U.S.C.A. $\S 1983$ (West 2011); 42 U.S.C.A. $\S 1988$ (b) (West 2011).

199. Lund, supra note 1 , at $490-91$ (observing that three of the then sixteen extant state RFRAs contain notice and exhaustion requirements and suggesting legal practice and faimess issues which may arise from their enforcement).

200. Id. at 491-93 (reviewing state RFRA coverage exclusions).

201. Id. at 480 .

202. Id. at $479-80$.

203. Id. at 481-82. Professor Lund points out that simple tallies of wins and losses do not tell the full story since the merits of each case will obviously vary, but the fact that more than half of the jurisdictions with miniRFRAs have no litigated victories has some significance. Id. at 482 .

204. See id. at 487-89.

205. See id. at $485-87$. 
James W. Wright, Jr. also has observed the minimal success enjoyed by religious adherents under mini-RFRAs. ${ }^{206}$ To understand these outcomes, Wright examined the underlying legislative findings leading to the adoption of mini-RFRAs. ${ }^{207} \mathrm{He}$ observed "the noticeable discrepancy"208 among RFRAs in this respect. ${ }^{209}$ For example, he points to seven states which have no legislative finding within their state RFRAs, ${ }^{210}$ and others "which . . . include a modest sentence outlining the purpose of the Act." ${ }^{211}$ In contrast to these states, Wright points to two others which adopted legislative findings which clearly amplify the RFRA's purpose, ${ }^{212}$ and make it evident the intent was to return to pre-Smith standards. ${ }^{213}$ Wright points out the mere fact of RFRA enactments and their uniform inclusion of a compelling interest test makes the purpose of the Acts obvious. ${ }^{214}$ That said, more definitive legislative findings statements of purpose might have led to better outcomes for religious adherents. Proposals to address these and other deficiencies are discussed in Part VII infra.

Wright also observed that there is significant variation among the mini-RFRAs in defining what a burden on religion is for purposes of activating strict scrutiny analysis. $^{215}$ He shows that satisfying this threshold requirement has posed major obstacles to those seeking religious accommodations, ${ }^{216}$ and proposes legislative reform focused on this aspect of statutory drafting. ${ }^{217}$

Wright's recommendation is to broaden the definition of what a religious burden is by including a wide range of individually faith driven decisions resulting in conduct or expressions and not merely those emanating from formally organized systems. ${ }^{218}$ Wright favors the definition of substantial burden contained in Pennsylvania's RFRA. $^{219}$ He contends its breadth most effectively limits judicial discretion ${ }^{220}$ and notes that "Pennsylvania's approach is correct."221 Because Wright's proposal may

206. See James W. Wright, Jr., Making State Religious Freedom Restoration Amendments Effective, 61 ALA. L. REV. 425, 435 (2010).

207. Id. at $430-32$.

208. Id. at 431 .

209. Id.

210. These states are: Connecticut, Florida, Idaho, New Mexico, Oklahoma, Rhode Island, and Texas. Id. at $431 \&$ n. 46 .

211. Id. at 431. These states include Arizona and Pennsylvania. Id. at n.47.

212. Id. at 431-32. These states include Illinois, South Carolina., and Alabama. Id. at $431 \mathrm{nn} .48-49$.

213. Id. at 431-32.

214. Id. at 432 (arguing "the purpose of these acts is clear - to restore the compelling interest test struck down in Smith and again in Boerne").

215. Id. at 433-35.

216. See id. at 433 (characterizing the problem of plaintiff proving a substantial burden as the most substantial bar to a successful claim under state RFRAs); $i d$. at 438-44 (discussing the issue and illustrating the consequences of legislative failure to define burdens on religion).

217. See id. at 434. Wright observed that among the RFRAs he studied, eight failed to provide guidance regarding the meaning of the statutory burden it created, and these were the states in which "plaintiffs are least likely to mount a successful Free Exercise claim against government action." Id. at 434 .

218. See id. at $442-44$.

219. Id. at 434.

220. See id.

221. Id. at 434. The Pennsylvania Religious Freedom Protection Act, 71 PA. STAT. ANN. $§ \S 2401-2407$, states in relevant part: 
not be sufficient to overcome the difficulties religious adherents have experienced in $\mathrm{K}-12$ settings, this article argues for the creation of specific statutory entitlements for religious exercise, drawn from disputes reaching federal appellate courts.See infra Part VII. This should further narrow executive and judicial discretion in denying religious accommodations.

Wright further observes a trend in the cases of applying Smith-type rational basis standards to state laws of general applicability despite direction in the RFRAs to apply a compelling state interest standard when religious burdens arise. ${ }^{222}$ In effect, once the court determines the law is one of general applicability, it becomes a defense to the suits brought under the state RFRA, perhaps a conclusive one. ${ }^{223}$ Indeed, the raison d'etre of state RFRAs was to reject Smith. ${ }^{224}$ Finally, judicial refusal to enforce mini-RFRAs raises separation of power questions, as between state legislative branches and the judicial departments, as well as about weaknesses in legislative drafting, which demand answers.

\section{State RFRA Litigation in Public Education}

Since no state RFRA contains an exception for religious liberty exercised in public K-12 settings, it is somewhat surprising how infrequently state RFRAs have been used by parents seeking accommodations from public education requirements.

The most significant case to arise under a state RFRA in the public education context is A.A. ex rel Betenbaugh $v$. Needville Independent School District, ${ }^{225}$ decided by the Fifth Circuit in $2010 .{ }^{226} A$.A. involved an enforcement proceeding under the Texas Religious Freedom Restoration Act ("TRFRA"). ${ }^{27}$ That law stated:

(a) Subject to Subsection (b), a government agency may not substantially burden a person's free exercise of religion. (b) Subsection (a) does not

(a) General rule. Except as provided in subsection (b), an agency shall not substantially burden a person's free exercise of religion, including any burden which results from a rule of general applicability. (b) Exceptions. An agency may substantially burden a person's free exercise of religion if the agency proves, by a preponderance of the evidence, that the burden is all of the following: (1) In furtherance of a compelling interest of the agency. (2) The least restrictive means of furthering the compelling interest.

Id. $\S 2404$ (emphasis added). The Pennsylvania RFPA states that a "substantial burden" arises where:

An agency []does any of the following: (1) Significantly constrains or inhibits conduct or expression mandated by a person's sincerely held religious beliefs. (2) Significantly curtails a person's ability to express adherence to the person's religious faith. (3) Denies a person a reasonable opportunity to engage in activities which are fundamental to the person's religion. (4) Compels conduct or expression which violates a specific tenet of a person's religious faith. 71 PA. STAT. ANN. $\S 2403$.

Id. $\S 2403$.

222. Wright, supra note 239 , at $435-38$ (reviewing judicial analyses and showing how Smith standards have crept into the courts' rationales).

223. Id. at 438.

224. Id. Wright expresses particular concern over the fact that this creeping version of Smith standards has occurred in states where the lion's share of state RFRA litigation has arisen. These states are Connecticut, Florida, and Illinois. $I d$. at 435-38.

225. 611 F.3d 248 (5th Cir. 2010).

226. Id. at 248 .

227. Id. at 257 . 
apply if the government agency shows that the application of the burden to the person: (1) is in furtherance of a compelling governmental interest; and (2) is the least restrictive means of furthering that interest. (c) A government agency that makes the demonstration required by Subsection (b) is not required to separately prove that the remedy and penalty provisions of the law, ordinance, rule, order, decision, practice, or other exercise of governmental authority that imposes the substantial burden are the least restrictive means to ensure compliance or to punish the failure to comply. ${ }^{228}$

In Betenbaugh, a Native American kindergarten student and his parents sued the school district, alleging that an exemption granted from the district's grooming policy was insufficient to satisfy the requirements of the TRFRA. ${ }^{229}$ The policy required that "[b]oys' hair shall not cover any part of the ear or touch the top of the standard collar in back." ${ }^{230}$ The rule was predicated on the school's interest in preventing disruption, avoiding safety hazards, and promoting discipline through the school's assertion of authority. ${ }^{231}$ A.A. maintained a "religious belief . . that long hair is ... an expression of his ancestry and heritage, [and] a sacred symbol of his life and experience in this world, and that it should be cut only to mark major life events such as the death of a loved one." 232 In his request for an exemption, A.A. alleged that his "hair had never been cut." ${ }^{, 233}$ In accommodating A.A.'s request the district offered two options: A.A. could wear “a single 'tightly woven' braid tucked behind [his] shirt or a bun on top of his head." ${ }^{, 234}$ A.A. deemed the offer insufficient. ${ }^{235}$

In analyzing the adequacy of the District's offer under the TRFRA, the Fifth Circuit applied the four-part test under which the claimant must show:

(1) that the government's regulations burden the plaintiff's free exercise of religion and (2) that the burden is substantial. If the plaintiff manages that showing, the government can still prevail if it establishes that (3) its regulations further a compelling governmental interest and (4) that the regulations are the least restrictive means of furthering that interest. ${ }^{236}$

This test places the burden of proving a substantial burden on the claimant and the burden of establishing a compelling state interest on the government. ${ }^{237}$

TRFRA defines "free exercise of religion" as "an act or refusal to act that is

228. Tex. Civ. Prac. \& Rem. Code ANN. § 110.003 (West 1999).

229. See Betenbaugh, 611 F.3d at 254-57.

230. Id. at 253.

231. Id.

232. Id at 256 .

233. Id.

234. Id. at 257 .

235. See id.

236. Id. at 259. This test was announced by the Texas Supreme Court in Barr v. City of Sinton, 295 S.W.3d 287 (Tex. 2009). Id.

237. Betenbaugh, 611 F.3d. at at 259 n.29 (citing Barr, 295 S.W. 3d at 307). 
substantially motivated by sincere religious belief." 238 In assessing the claimant's religious beliefs, TRFRA directs that "it is not necessary to determine that the act or refusal to act is motivated by a central part or central requirement of the person's sincere religious belief." 239 The court concluded that A.A. had a sincere religious belief in wearing his hair visibly long such that the alternatives proposed by the District would be inconsistent with that belief. ${ }^{240}$ This conclusion was supported by the fact that the student and parents had consistently maintained that the student's long hair was "not only an expression of his ancestry and heritage, but also a sacred symbol of his life.",241

In analyzing the "substantial burden" question under the TRFRA, the court concluded that the interference must be one which "is real [versus] merely perceived, and significant [versus] trivial." 242 This requires a finding on "the degree to which a person's religious conduct is curtailed and the resulting impact on his religious expression," as "measured . . . from the person's perspective, not from the government's." 243 Following Barr v. City of Sinton, ${ }^{244}$ and its progeny, the Betenbaugh court indicated that the substantial burden inquiry requires a "case-bycase"245 and "fact-specific" 246 analysis, and must take into account personal circumstances. ${ }^{247}$ It concluded that even when a restriction on religious conduct is not completely prohibitive, it is still a substantial burden if "alternatives for the religious exercise are severely restricted" 248 and it "impacts religious expression to a 'significant' and 'real' degree." 249 The court held the burden on A.A. was significant. $^{250}$

In continuing with its individual inquiry the Fifth Circuit observed that A.A. could not visibly wear his hair long at a critical time in his young life. ${ }^{251}$ It also noted the indirect burdens that resulted. ${ }^{252}$ The District's proposed accommodations would make A.A. "stand out as someone subject to official stigma." ${ }^{253}$ Moreover, if A.A. refused to accept the District's offer, he would be exposed to punishment for violating the school's policy. ${ }^{254}$ Finally, the reality was that A.A. was aware he was being treated differently because of his religious beliefs, and the threat of adhering to his

238. Tex. Civ. Prac. \& REM. CODE ANN. § 110.001(a)(1) (West 1999).

239. Id.

240. See Betenbaugh, 611 F.3d. at 262-63.

241. Id. at 261-63.

242. Id. at 264 (quoting Barr, 295 S.W. $3 \mathrm{~d}$ at 301). The breadth of these criteria led the court to conclude that these limitations "leave a broad range of things covered." Id. (quoting Barr, 295 S.W.3d at 301).

243. Id. at 264 (quoting Barr, 295 S.W.3d at 301) (internal quotations omitted).

244. 295 S.W.3d 287 (Tex. 2009).

245. Betenbaugh, 611 F.3d. at 264 (quoting Barr, 295 S.W.3d at 302).

246. Id. (quoting Barr, 295 S.W.3d at 302).

247. Id. (citing Barr, 295 S.W.3d at 308, and Merced v. Kasson, 577 F.3d 578, 590 n. 65 (5th Cir. 2009).

248. Id. at 265 (quoting Barr, 295 S.W.3d at 305).

249. Id. at 265 (quoting Barr, 295 S.W.3d at 301).

250. Id. at 265 .

251. Id.

252. Id. at 266 .

253. Id.

254. Id. 
religious practice was his continuing to risk feelings of shame and resentment. ${ }^{255}$

The $A . A$. court next examined the District's duty to establish a compelling state interest for the policy. ${ }^{256}$ It emphasized that in order to establish a compelling interest under TRFRA, statements of general interests, standing alone, will be insufficient, ${ }^{257}$ and that the State's burden may be carried only by showing that the restriction on religious liberty is justified "with respect to the 'particular practice' at issue." 258 This standard requires the court to make a searching examination of the interest the State wishes to promote and the impediment to those goals that would result from recognizing the exemption sought by the religious adherent. ${ }^{259}$ Thus, "general platitudes" from the government will not suffice; it must show, with specific evidence, how the religious practice jeopardizes its stated interests. ${ }^{260}$

Applying these criteria, the court concluded that the school's interests in teaching hygiene, preventing disruption, and avoiding safety hazards were not compelling interests that justified, under TRFRA, the burden on A.A.'s religious practice. ${ }^{261}$ Indeed, A.A.'s hair was kept clean and it posed no cognizable safety concern. ${ }^{262}$ Moreover, the court concluded that although "the wearing of long hair and unconventional dress by most boys [could] be seen as an act of defiance-and a rejection of authority," A.A.'s long hair was not an act of rebellion, but simply adherence to his religious belief. ${ }^{263}$ In short, the district's justification for enforcing its "accommodation" to A.A. was extremely thin and definitively rejected by the court's majority. ${ }^{264}$

In Combs v. Homer Center School District ${ }^{265}$ the court construed a parent's Free Exercise claim under the Pennsylvania Religious Freedom Protection Act (PRFPA) ${ }^{266}$ The issue in Combs involved oversight by a local school district of home-schooling programs, as required by the state statute. ${ }^{267}$ It required minimum numbers of days and hours of instruction in certain subjects and compelled parents to submit a portfolio of teaching logs and the children's work product for review. ${ }^{268}$

255. Id.

256. Id. at 266-72.

257. Id. at 268 .

258. Id. (quoting Barr v. City of Sinton, 295 S.W.3d 287, 306 (Tex. 2009)) (emphasis added)

259. Id.

260. Id.

261. Id. at 268-69.

262. Id. at 268. The court also rejected the District's argument that avoidance of those occasions where A.A. was mistaken for a girl triggered a compelling interest by the District to justify burdening this religious practice. Id. at 269 .

263. Id. at 271. The court further observed that the District had not shown that, since it permitted girls to wear their hair visibly long, any safety concerns had arisen with respect to girls or that any gender confusion or conflict arose where girls had chosen to wear their hair short. Id. at 271-72.

264. Id at 272 . The absence of a compelling state interest made it unnecessary for the court to apply the "narrowly tailored" provision of the TRFRA. Id. at $266 \mathrm{n} .72$. That rule demands that the substantial burden on Free Exercise be removed. Id. at 266.

265. 468 F.Supp. 2d 738 (W.D. Pa. 2006), aff'd in part, vacated in part, and remanded sub nom. Combs v. Homer-Ctr. Sch. Dist., 540 F.3d 231 (3d Cir. 2008).

266. See Pennsylvania Religious Freedom Protection Act, 71 PA. STAT. ANN. §§ 2401, 2407, n. 220.

267. See Combs v. Homer Ctr. Sch. Dist., 468 F.Supp. 2d 738, $739-40$ (W.D. Pa. 2006).

268. Id. 
Further, it mandated that the parents show adequate progress in the overall program. ${ }^{269}$ Under the Act, the school district did not review educational content, textbooks, curriculum, instructional materials, or methodology. ${ }^{270}$ The plaintiffs sought an exemption from the requirements on the ground that both the record keeping and portfolio obligations violated their religious liberty under the PRFPA. ${ }^{271}$ The parents asserted that the Act compelled "conduct or expression" by requiring them to submit the content and records of their children's progress to the school district. ${ }^{272}$ On appeal, they claimed, this violated a "specific tenet" of their religion that "education of their children, not merely religious education, is religion and is assigned by God to the jurisdiction of the family."273

In applying the fourth substantial burden test contained in the statute ("Compels conduct or expression which violates a specific tenet of a person's religious faith"274), the court concluded the plaintiffs had failed to establish by clear and convincing evidence that they suffered a substantial burden on their religious freedom and dismissed their claim. ${ }^{275}$

On appeal, the Third Circuit dismissed plaintiffs' federal constitutional claims and declined to exercise supplemental jurisdiction. ${ }^{276}$ It vacated the district court's order applying the PRFPA and remanded that claim to the district court with instructions to in turn remand it to state court for disposition. ${ }^{277}$ The Third Circuit noted that no authoritative state court had interpreted the "compels conduct or expression which violates a specific tenet of a person's religious faith" provision of the statute. ${ }^{278}$ Thus, the Combs court rejected the opportunity to recognize the statute's apparently broad definition of religious burdens, ${ }^{279}$ leaving unsettled the reach of this provision.

Betenbaugh and Combs show how otherwise easily solved problems involving religious exercise can result in litigation due to the failure of school officials to make simple programmatic adjustments for religious interests. They also illustrate the need for more effective legislative remedies to prevent such conflicts from arising in the first instance.

269. See id. at 746.

270. Id. at 740 .

271. Id. at 753-61.

272. Id.

273. Combs v. Homer-Ctr. Sch. Dist., 540 F.3d 231, 252, 253 (3d Cir. 2008)(The legislative proposal in Part VII also requires that the parents establish an infringement on religious exercise by a preponderance of the evidence.See infra at 73.

274. See Combs v. Homer Ctr. Sch. Dist., 468 F.Supp. 2d 738, 771 (W.D. Pa. 2006).

275. Id. at 771 .

276. Combs v. Homer-Ctr. Sch. Dist., 540 F.3d 231, 252, 254 (3d Cir. 2008).

277. Id. at 254 .

278. Id. at 253-54.

279. See Wright, supra note 239, at 434-35 (ranking the Pennsylvania Act as one of the broadest in recognizing religious burdens). 


\section{THE QUEST FOR RELIGIOUS ACCOMMODATIONS TO PUBLIC EdUCATION REQUIREMENTS}

Part A of this section briefly reviews the United States Supreme Court decisions rendered in the K-12 religious accommodation arena. Part B illustrates the broad range of $\mathrm{K}-12$ religious accommodation issues confronted by the United States Courts of Appeal during the last half-century. Part C shows how K-12 religious exercise conflicts break down by dispute category. Part $\mathrm{D}$ empirically examines the decisional outcomes involving public $\mathrm{K}-12$ religious accommodation disputes during the Sherbert and Smith eras in the circuits. It illustrates conclusively the extraordinary difficulty religious adherents have had in getting relief in the circuit courts, irrespective of when their claims were brought.

\section{A. United States Supreme Court Decisions}

Conflicts between adherents seeking religious accommodations and educational agencies that have reached the United States Supreme Court have included disputes over compelled public school attendance, ${ }^{280}$ ages for required attendance, ${ }^{281}$ and prohibitions on teaching foreign languages in public or private schools. ${ }^{282}$ They have also included disputes concerning state sanctioned release time from compulsory education to receive religious instruction on school grounds during regular school hours, ${ }^{283}$ as well as release time during regular school hours to receive religious instruction off-campus. ${ }^{284}$ Famously, they have included disputes over compelled flag salutes and mandatory recitation of the Pledge of Allegiance ${ }^{285}$ and parental resistance to state immunization requirements as a condition of students attending public school. $^{286}$

280. See Pierce v. Soc'y of Sisters of the Holy Names of Jesus \& Mary, 268 U.S. 510 (1925); see also supra note 36 and accompanying text and infra note 341 and accompaning text.

281. See Wis. v. Yoder, 406 U.S. 205 (1972); see also supra notes 23-45, 112, 163 and accompaning text text and infra note 193 and accompanying text; see also discussion supra p. 34 and infra p. 54.

282. See Meyer v. Neb., 262 U.S. 390 (1923)(state law prohibiting education in language other than English unconstitutionally interferes with the substantive due process right of parents to control the upbringing of their children).

283. See Illinois ex rel. McCollum v. Bd. of Educ. of Sch. Dist. No. 71, 333 U.S. 203, 212 (1948) (holding that the use of the tax-established and tax-supported public school system to aid religious groups to spread their faith to students compelled by the State to attend those schools, falls squarely under the ban of the First Amendment).

284. See Zorach v. Clauson, 343 U.S. 306 (1952) (approving off-campus release time as an accommodation to the religious needs of the people observing). The Court observed in Zorach that the Establishment Clause does not require [schools] "to be hostile to religion or throw [their] weight against efforts to widen the effective scope of religious influence" and that schools "can close [their] doors or suspend [their] operations as to those who want to repair to their religious sanctuary for worship or instruction. No more than that is undertaken here." Id. at 314 .

285. See W. Va. State Bd. of Educ. v. Barnette, 319 U.S. 624, $641-42$ (1943) (concluding that "compelling the flag salute and pledge transcends constitutional limitations on [school officials'] power and invades the sphere of intellect and spirit which it is the purpose of the First Amendment. . to reserve from all official control").

286. See Jacobson v. Massachusetts, 197 U.S. 11, $27-29$ (1905) (holding that the State may adopt a program of compulsory small pox immunization for inhabitants of a town, including school aged-children); Zucht $\mathbf{v}$. King, 260 U.S. 174, 176 (1922) (holding that the State may adopt a program of compulsory immunization for 


\section{B. Decisions from the United States Courts of Appeal Involving Constitutional Claims}

\section{Categories of K-12 Religious Accommodation Claims}

Religious adherents have challenged a public school's decision to deny academic credit to released-time attendees where the courses in which the students enrolled were "mainly denominational" in content. ${ }^{287}$ Others have challenged procedures which place on public schools the burden of gathering a seminary's attendance slips in satisfaction of state requirements. ${ }^{288}$ Moreover, conflict has arisen where students have contended that they have a right to meet on school premises for communal prayer meetings immediately before the school day commenced. ${ }^{289}$ Litigation has ensued where a school refused to recognize an afterschool Bible club whose rules guaranteed that its president, vice president, and choral leader be Christians because the club's rules were inconsistent with the school's generally applicable nondiscrimination policy. ${ }^{290}$

In-school disputes have included those over compelled flag salutes and recitation of the Pledge of Allegiance, ${ }^{291}$ and students' exposure to religiously objectionable material. With respect to the latter, parents have sought religious exemptions from studying a mandated elementary reading series, ${ }^{292}$ using home economics, history

school-aged children).

287. See Lanner v. Wimmer, 662 F.2d 1349, 1360-62 (10th Cir. 1981) (invalidating part of a release-time program that awarded academic credit for some religious courses - but not for those found to be "mainly denominational"- because the program unconstitutionally entangled the State in examining and monitoring the religious content of courses; however, the State can require that release-time courses for which credit is granted to fulfill certain secular criteria, and such requirement does not offend Establishment Clause strictures); see also Moss v. Spartansburg Cnty. Sch. Dist. Seven, 683 F.3d 599, 609-11 (4th Cir. 2012) (holding that the public school's policy of allowing academic credit for off-campus release-time religious instruction from accredited schools did not violate the Establishment Clause, since it was neutrally administered and had the secular purpose of accommodating students' desire to receive religious instruction).

288. See Lanner, 662 F.2d at 1358-59 (holding that First Amendment Establishment Clause requirements were violated when the public school assumed the burden of gathering seminary attendance slips at private religious school for released-time students, because there was a less entangling alternative of requiring releasedtime personnel to transmit attendance reports to public school).

289. See Brandon v. Bd. of Educ. of the Guilderland Cent. Sch. Dist., 635 F.2d 971, 977 (2d Cir. 1980) (finding that students' Free Exercise rights were not limited by school board's refusal to permit communal prayer meetings to occur on school premises, and that permitting such activity would have created an unlawful establishment by linking the school to church activities).

290. Hsu v. Roslyn Union Free Sch. Dist. No. 3, 85 F.3d 839, 868-70 (2d Cir. 1996) (holding that exemption of club from the school's generally applicable nondiscrimination policy would not constitute invidious discrimination against non-believers under the Equal Protection Clause).

291. See, e.g., Freedom from Religion Found. v. Hanover Sch. Dist., 626 F.3d 1, 14-16 (1st Cir. 2010) (holding that students' exposure to recitation of Pledge of Allegiance neither violated students' nor parents' ability to freely believe in atheism or agnosticism under Free Exercise Clause, nor their right to Equal Protection of the laws). Every federal circuit court that has addressed a state pledge statute has rejected the claim of unconstitutionality. See, e.g., Croft v. Perry, 624 F.3d 157 (5th Cir. 2010); Newdow v. Rio Linda Union Sch. Dist., 597 F.3d 1007 (9th Cir. 2010); Myers v. Loudoun Cnty. Pub. Sch., 418 F.3d 395 (4th Cir. 2005); Sherman v. Cmty. Consol. Sch. Dist. 21 of Wheeling Twp., 980 F.2d 437 (7th Cir. 1992).

292. Mozert v. Hawkins Cnty. Bd. of Educ., 827 F.2d 1058, 1060-61 (6th Cir. 1987) (rejecting parents' Free Exercise claim concerning grade 1-8 reading series which contained books purported to teach "higher order cognitive skills" and discussed "'mental telepathy"). 
and social studies textbooks, ${ }^{293}$ and portions of a curriculum for first through sixth graders based on the students' exposure to material contained in a reading series. ${ }^{294}$ Litigation has occurred as well over introduction into the first, second, and third grade curricula material that seemed to endorse homosexual relationships. ${ }^{295}$ Taxpayerparents have complained where the school district opened a school primarily attended by a particular religious group and granted the attendees exemptions from use of technology. ${ }^{296}$ Parents have even asserted infringements on their religious liberty based on in-school Earth Day celebrations. ${ }^{297}$ Prominent of course, has been the spate of parents' religiously based litigation in the evolution versus creationism conflict. $^{298}$

Other curriculum disputes have arisen over mandated health education classes, ${ }^{299}$

293. See, e.g., Smith v. Bd. of Sch. Comm'rs of Mobile Cnty., 827 F.2d 684, 692-93 (11th Cir. 1987) (holding that the use of home economics, history and social studies textbooks did not violate the Establishment Clause by advancing secular humanism or by inhibiting theistic religion).

294. See, e.g., Brown v. Woodland Joint Unified Sch. Dist., 27 F.3d 1373, 1384 (9th Cir. 1994) (rejecting claim that curriculum which asked children to discuss witches and create poetic chants and pretend they were witches or sorcerers did not require children to practice "religion" of witchcraft in violation of Establishment Clause); Fleischfresser v. Directors of Sch. Dist. 200, 15 F.3d 680, 683, 689-90, 695 (7th Cir. 1994) (rejecting Establishment and Free Exercise Clause claims that reading series indoctrinated children in anti-Christian beliefs by teaching about "wizards, sorcerers, giants, and unspecified creatures with supernatural powers, among other things").

295. See Parker v. Hurley, 514 F.3d 87, 90, 105 (1st Cir. 2008), cert. denied, 129 S.Ct. 56 (2008) (rejecting claim of parents who objected to an elementary school's use of children's books which described families with same-sex parents on ground that the school was trying to indoctrinate their children with the belief that homosexual marriage is acceptable).

296. See Stark v. Indep. Sch. Dist., No. 640, 123 F.3d 1068, 1075-77 (8th Cir. 1997) (holding that neither the opening of the school attended primarily by adherents of one particular religious group nor granting exemptions from the use of technology violated Establishment Clause; because there was no endorsement of religion, the school district did not delegate any control of educational system to adherents, and the exemptions were uniformly granted to students whose parents requested them).

297. Altman v. Bedford Cent. Sch. Dist. v. 245 F.3d 49 (2d Cir. 2001) (holding that celebration of Earth Day did not violate the Establishment or Free Exercise Clauses).

298. The Supreme Court first addressed this issue in 1968 in Epperson v. State of Arkansas, 393 U.S. 97 (1968), where it held that a statute which forbade the teaching of evolution was unconstitutional. Id. at 109. Then, in 1987, the Court held that a Louisiana statute requiring balanced treatment of creation science and evolutionary science was facially invalid as an establishment of religion. Edwards v. Aguillard, 482 U.S. 578, 593-94 (1987). In Freiler v. Tangipahoa Parish Board of Education, 185 F.3d 337 (5th Cir. 1999), rehearing en banc denied, 201 F.3d 602 (5th Cir. 2000), cert. denied, 530 U.S. 1251 (2000), the Fifth Circuit held that a disclaimer devised by the school board concerning the scientific theory of evolution violated the Establishment Clause on the ground that it had the primary effect of protecting and maintaining a particular religious viewpoint and endorsing religion. Id. at 346-48.

299. Leebaert v. Harrington, 332 F.3d 134 (2d Cir. 2003) (rejecting Free Exercise and Due Process and "hybrid Free Exercise" claims by asserting that excusal from seventh-grade health education classes was not constitutionally mandated. Id. at 142-43, 144-45). 
AIDS awareness and sex education, ${ }^{300}$ and compelled participation in ROTC ${ }^{301}$ Still other disputes have encompassed mandated community service requirements, with no exceptions or opt-out provisions, as a graduation requirement. ${ }^{302}$ Moreover, litigation has ensued over a condom distribution program. ${ }^{303}$ Such disputes have included claims of Free Exercise infringement when a student was disciplined for failing to follow pre-clearance procedures for valedictorian speech and giving a speech with religious content. ${ }^{304}$ Litigation has ensued over procedural rules that require students enjoying a religious exemption to reapply annually for its continuation. $^{305}$ Disputes have arisen over a music teacher's selection of explicitly Christian music and Christian religious sites for performance. ${ }^{306}$ Moreover, parents

300. See C.N. v. Ridgewood Bd. of Educ., 430 F.3d 159, 184-185, n.26 (3d Cir. 2005) (holding that parents' Due Process rights "to make decisions concerning the care, custody, and control of their children" was not violated by school district's request that students complete a survey regarding their private lives, including inquiries about drug and alcohol use and sexual activity, for use in planning community youth activities, even if no parental consent for participation was sought); Fields v. Palmdale Sch. Dist. (PSD), 427 F.3d 1197, 1207 (9th Cir. 2005) (holding that although parents enjoy the right to control the upbringing of their children by introducing them to matters of and relating to sex, that right does not extend beyond the threshold of the school door to control in-school instruction in such matters); Brown v. Hot, Sexy and Safer Prod., Inc., 68 F.3d 525, 539 (1st Cir. 1995), cert. denied, 516 U.S. 1159 (1996) (rejecting claim students' compelled attandance at sexually explicit AIDS awareness and sex education program was unconstitutional); Cornwell v. State Bd. of Educ., 314 F. Supp. 340 (D. Md. 1969), aff'd, 428 F.2d 471 (4th Cir. 1970), cert. denied, 400 U.S. 942 (1970) (rejecting parents' application to enjoin family life and sex education program in elementary and secondary schools on First Amendment and Due Process grounds).

301. Spence v. Bailey, 465 F.2d 797, 799-800 (6th Cir. 1972) (holding that school district infringed on "conscientiously object[ing]" student's Free Exercise rights by insisting that he complete an R.O.T.C. course to satisfy the state physical education requirement and receive his diploma). The court in Spence noted that a less burdensome alternative on student's religious beliefs was readily available, since the student could have readily achieved the curricular requirement at a facility located less than one hundred yards from the student's school. Id. at 799 .

302. See, e.g., Herndon v. Chapel Hill-Carrboro City Bd. of Educ. 89 F.3d 174, 179-80 (4th Cir. 1996) (holding that the school district's mandatory community service program did not infringe on "parents' right to direct the upbringing of their child"); Immediato v. Rye Neck Sch. Dist., 73 F.3d 454, 463 (2d Cir. 1996) (holding that school district's mandatory community service program did not violate parents' individual liberty interest or student's right of privacy); Steirer v. Bethlehem Area Sch. Dist., 987 F.2d 989, 995-97 (3d Cir. 1993) (rejecting claim that community service program violated student's rights since it compelled him to affirm a philosophy of altruism, among other reasons).

303. See, e.g., Parents United for Better Schools, Inc. v. Sch. Dist. of Philadelphia Bd. of Educ., 148 F.3d 260, 274-75 (3d Cir. 1998) (rejecting parents' claim that voluntary high school condom distribution program violated their "fundamental right to remain free from unncessary governmental interference with bringing up their children").

304. Corder v. Lewis Palmer Sch. Dist. No. 38, 566 F.3d 1219, 1233 (10th Cir. 2009) (holding that student was disciplined not for her religious views, but rather for failing to follow the religion-neutral policy, applicable to school-sponsored graduation ceremonies, and for deceiving the principal concerning the content of the speech she would give). In a non-student case, Carpenter v. Dillon Elementary Sch. Dist. 10, 149 F. App'x 645 (9th Cir. 2005), the court dismissed a minister's claim asserting that the school district violated his First Amendment rights "by granting and thereafter revoking permission" to speak at a school assembly. Id. at 646 . The court held that permission to speak at a school assembly was not a "valuable governmental benefit" and that therefore revoking the offer did not violate the First Amendment. Id. at 646-47.

305. See, e.g., Littlefield v. Forney Indep. Sch. Dist., 268 F.3d 275, 293-94 (5th Cir. 2001) (concluding that school's opt-out procedure, which mandated that parents annually apply for a religious exemption from school's dress code policy by filling out a questionnaire designed to test the sincerity of their beliefs, did not burden parents' Free Exercise and Establishment Clause rights).

306. Bauchman v. W. High Sch., 132 F.3d 542, 556-58 (10th Cir. 1997) (holding that, where student member of school choir failed to allege facts showing that she was coerced into singing songs contrary to her 
have sought exemptions in such areas as vaccination requirements, ${ }^{307}$ and dress and grooming codes. ${ }^{308}$ Conflict has arisen as well in the wake of states enacting statutes permitting home-schooling. ${ }^{309}$ These disputes have been over such issues as the obligation of parents who home-school their children to comply with reporting and review requirements contained in compulsory education laws, ${ }^{310}$ and the right of home-schooled children to attend public school classes on a part-time basis. ${ }^{311}$ In the charter school arena, parents have objected to a State policy that prohibited the use of sectarian or denominational textbooks as part of the school curriculum. ${ }^{312}$ Disputes have arisen about student-athletes' right to wear religious accoutrements during interscholastic competition. ${ }^{313}$

In the private school arena, litigation has resulted over the extent to which public schools were mandated to furnish educational services to students enrolled in private

religious beliefs, no Free Exercise cause of action was stated).

307. See, e.g., Friedman v. Clarkstown Cent. Sch. Dist., 75 F. App'x 815, 820 (2d Cir. 2003) (holding that no Free Exercise violation occurred where superintendent, pursuant to regulation, asked parent to submit documentation to support her request for an exemption, and that the regulation did not burden the Free Exercise clause because it contained an express provision for religious exemptions to the immunization); McCarthy v. Boozman, 212 F.Supp. 2d 945, 948-49 (W.D. Ark. 2002), vacated as moot sub nom. McCarthy v. Ozark Sch. Dist., 359 F.3d 1029 (8th Cir. 2004) (holding that appeals of lower court's decision, which held that religious exemption to mandatory immunization program violated Free Exercise and Establishment Clauses, where it was limited to adherents and churches recognized by the state), vacated, 359 F.3d 1029, 1036-37 (8th Cir. 2004) (holding that appeal was moot after state legislature broadened exemptions "to encompass philosophical as well as religious objections").

308. On dress codes, see, e.g., Blau v. Fort Thomas Pub. Sch. Dist., 401 F.3d 381, 395-96 (6th Cir. 2005) (concluding that a "parent did not have a fundamental right to exempt his child from the school dress code"); Wilkins v. Penns Grove-Carneys Point Reg'l Sch. Dist., 123 F. App'x 493 (3d Cir. 2005) (rejecting Equal Protection claim of atheist mother who sought religious exemption from mandatory school uniform policy); see also Chalifoux v. New Caney Indep. Sch. Dist., 976 F. Supp. 659, 667 (S.D. Tex. 1997) (holding that school regulation prohibting students from wearing rosaries as necklaces violated their Free Exercise rights because it unduly burdened a "sincere expression of religious beliefs"). Chalifoux is a frequently cited case. On grooming codes, see, e.g., A.A. ex rel Betenbaugh v. Needville Independent School District, 611 F.3d 248 (5 $5^{\text {th }}$ Cir. 2010)(granting religious exemption from school regulation of student's hair length).

309. All fifty state legislatures have enacted laws permitting some form of home-schooling, although they vary widely in the rigor with which they direct supervision of the parents' educational activities. See generally Ralph D. Mawdsley, Directing Children's Education: The Changing Views of Courts and Legislatures, 171 EdUC. L. REP. 381 (2003); CHRISTINE M. FIELD, A FIELd GuIDE TO HOME SCHOOLING (1998).

310. See, e.g., Murphy v. State of Arkansas, 852 F.2d 1039, 1043-44 (8th Cir. 1988) (upholding State's use of achievement tests to monitor progress of home-schooled children of compulsory education age as against Free Exercise, Due Process, and Equal Protection challenges, despite the fact that such monitoring was not mandated for students who attended more formal and structured private schools); see also supra notes 265-279 and accompanying discussion.

311. Swanson v. Guthrie Indep. Sch. Dist., 135 F.3d 694, 697-700, 702 (10th Cir. 1998) (holding that school district's policy, requiring students to enroll on a full-time basis, did not unconstitutionally burden parents' right to direct their children's education or the home-schooled student's Free Exercise rights when she sought to enroll in foreign language, vocal music, and some science classes).

312. Nampa Classical Acad. v. Goesling, 447 F. App'x. 776 (9th Cir. 2011) (rejecting parents' claim, concluding that the Establishment Clause "generally prohibits governmental promotion of religion, not governmental efforts to ensure that government entities, or private parties receiving government funds, use public money for secular purposes").

313. Menora v. Illinois High Sch. Ass'n, 683 F.2d 1030, 1034-36 (7th Cir. 1982) (holding that athletic association's rule forbidding basketball players to wear hats or other headwear, with sole exception of headband no wider than two inches, while playing, did not violate Free Exercise Clause, but ordering the district court to retain jurisdiction so that complaining players could have opportunity to propose to athletic association a form of headcovering that complied with Jewish law, yet met association's safety concerns). 
religious schools. ${ }^{314}$ Litigation has also occurred when public school employees have suffered adverse employment decisions by enrolling their children in religious schools rather than in the district in which they worked, ${ }^{315}$ or for electing to homeschool them. ${ }^{316}$

\section{K-12 Court of Appeals Decisions and Defining "Religious Burdens"}

Demonstrating a religious burden in constitutional cases is of paramount importance, since it is the gatekeeper for such claims. A failure to demonstrate a sufficient burden will doom the claim from the start.

The Fourth, Ninth, and Eleventh Circuits define "substantial burden" as one that either compels the religious adherent to engage in conduct that his religion forbids or forbids him to engage in conduct that his religion requires. ${ }^{317}$ The Eighth and Tenth Circuits use a broader definition- -: action that forces religious adherents "to refrain from religiously motivated conduct," 318 or that "significantly inhibit[s] or constrain[s] conduct or expression that manifests some central tenet of a [person's] individual beliefs," 319 or imposes a substantial burden on the exercise of the

314. See, e.g., Gary S. v. Manchester Sch. Dist., 374 F.3d 15 (1st Cir. 2004). Gary S. examined parents' claim that the federal Individuals with Disabilities Education Act (IDEA) violated their Free Exercise rights because it furnished fewer services to their disabled son, who attended a Catholic elementary school, than he would have received if he attended a public school in their school district. See id. at 17. The court concluded "that no cognizable burden on religion has been caused by the federal government's failure to provide to disabled children attending Catholic schools the same benefits as it provides to disabled public school children $\ldots$... Id. at 21 . It anchored this conclusion on the proposition that "the mere non-funding of private secular and religious programs does not 'burden' a person's religion or the free exercise thereof." Id. at 21-22. The court observed: "[I]t is clear there is no federal constitutional requirement that private schools be permitted to share with public schools in state largesse on an equal basis." Id. at 20-21 (citations omitted). In Goodall by Goodhall v. Stafford Co. Sch. Bd., 60 F.3d 168, 171 -72 (4th Cir. 1995), the court rejected a Free Exercise claim similar to the one in Gary $S$. There the court said the State did not have to furnish a "cued speech transliterator" to a deaf child, despite the parties' stipulation that the child needed the service to benefit from instruction. Id.

315. See, e.g., Barrett v. Steubenville City Sch., 388 F.3d 967, 971-72 (6th Cir. 2004)(holding that elementary school teacher stated a claim under $\S 1983$ for alleged violations by superintendent of his constitutional right to rear his child by alleging that superintendent not only conditioned his full-time employment on where teacher's son attended school, but also terminated him once his son was removed from public school),; see also, Barrow v. Greenville Indep. Sch. Dist., 332 F.3d 844, 848 (5th Cir. 2003) (holding that a teacher, who was not considered for an assistant principal's position because she refused to re-enroll her children in public school, stated a claim for violation of her constitutional right to educate her children in private school).

316. See, e.g., Peterson v. Minidoka Cnty. Local Sch. Dist. No. 331, 118 F.3d 1351, 1358-60 (9th Cir. 1997), amended by, 132 F.3d 1258 (9th Cir. 1997) (holding that a school superintendent's order to reassign an elementary school principal to an elementary teaching position because the principal decided to home-school his children was a violation of his free exercise of religion and liberty interests).

317. See Goodall by Goodall v. Stafford Cnty. Sch. Bd., 60 F.3d 168, 172-73 (4th Cir.1995); Cheffer v. Reno, 55 F.3d 1517, 1522 (11th Cir.1995); Bryant v. Gomez, 46 F.3d 948 (9th Cir.1995) (per curiam). See Goodall v. Stafford Cnty. Sch. Bd., 60 F.3d 168 (4th Cir. 1995); Bryant v. Gomez, 46 F.3d 948 (9th Cir. 1995); Cheffer v. Reno, 55 F.3d 1517, 1522 (11th Cir. 1995)(holding that since plaintiffs failed to allege their religion required them to use physical force or threats of physical force or to obstruct clinic entrances to prevent abortions, the federal Access Act did not violate RFRA).

318. Brown-El v. Harris, 26 F.3d 68, 70 (8th Cir.1994) Brown-El v. Harris, 26 F.3d 68, 70 (8th Cir. 1994) (quoting United States v. Means, 858 F.2d 404, 407 (8th Cir. 1988), cert. denied, 492 U.S. 910 (1989)).

319. Wemer v. McCotter, 49 F.3d 1476, 1480 (10th Cir. 1995). 
individual's religion. ${ }^{320}$ The Sixth Circuit asks whether the law compels "affirma[nce] or denial of a religious belief, or the performance or non-performance of a religious exercise or practice. ${ }^{321}$ If it does not, then no burden has been established. $^{322}$

\section{Conflict Categories}

To observe these religious freedom issues from the perspective of a wide lens, this Article has grouped these decisions into seven categories derived from the sixtytwo K-12 religious accommodation decisions issued by United States Courts of Appeal between 1963 (the date of the Sherbert decision) and 2013 which appear in the Westlaw data base as indexed or published decisions. A letter designation has been assigned to each category along with a description of the kinds of disputes assigned to that category, the number of such disputes that were adjudicated, and the percent of the database represented by that category of dispute. Where a dispute fell into more than one category, I selected the one which came closest to the core issue the case. Table 1 displays the results. ${ }^{323}$

Table 1: Distribution of United States Courts of Appeal K-12 Religious Accommodation Decisions between 1963-2013 by Conflict Category

\begin{tabular}{|c|l|l|l|}
\hline $\begin{array}{c}\text { Category } \\
\text { Designation }\end{array}$ & \multicolumn{1}{|c|}{ Category Description } & N & $\begin{array}{c}\text { \% of } \\
\text { Decisions }\end{array}$ \\
\hline A & $\begin{array}{l}\text { Student religious group meetings, group } \\
\text { membership, and communal prayer. }\end{array}$ & 5 & $8.1 \%$ \\
\hline B & $\begin{array}{l}\text { Opt-out or strike objectionable curriculum } \\
\text { or school activities, including holiday } \\
\text { displays/songs. }\end{array}$ & 33 & $53.2 \%$ \\
\hline C & Student dress. & 5 & $8.1 \%$ \\
\hline D & $\begin{array}{l}\text { Scheduling of classes or events/holiday } \\
\text { absences/release time. }\end{array}$ & 2 & $3.2 \%$ \\
\hline E & Student Health and Safety & 5 & $8.1 \%$ \\
\hline
\end{tabular}

320. Id.

321. Mozert v. Hawkins Cnty. Bd. of Educ., 827 F.2d 1058, 1065 (6th Cir. 1987).

322. See id; see also Wallace by and through Wallace v. Knox Cnty. Bd. of Educ. 1 F.3d 1243 (6th Cir. 1993) (unpublished opinion).

323. The conflict categories contained in Table 1 were substantially derived from those used by Professor Berg. See Thomas C. Berg, State Religious Freedom Statutes in Private and Public Education, 32 U.C. Davis L. REV. 531, 549-72 (1999). 


\begin{tabular}{|c|l|l|l|}
\hline F & $\begin{array}{l}\text { Private or Home School's Curriculum or } \\
\text { Teacher Qualifications/student evaluation. }\end{array}$ & 3 & $4.8 \%$ \\
\hline $\mathrm{G}$ & $\begin{array}{l}\text { Denial of educational benefits, including } \\
\text { financial support to private school or its } \\
\text { students, or under home-schooling } \\
\text { program, or permission to participate in } \\
\text { interscholastic sports. }\end{array}$ & 6 & $9.7 \%$ \\
\hline $\mathrm{H}$ & $\begin{array}{l}\text { Retaliation or unconstitutional conditions } \\
\text { in public employment. }\end{array}$ & 2 & $3.2 \%$ \\
\hline I & $\begin{array}{l}\text { Provision of financial support to religious } \\
\text { set in community. }\end{array}$ & 1 & $1.6 \%$ \\
\hline
\end{tabular}

These conflict areas will be examined more closely below, especially in the discussion about legislative reform and conflict avoidance. ${ }^{324}$

\section{Empirical Analysis of Decisional Outcomes}

Table 2 shows the outcomes for United States Courts of Appeals decisions issued between 1963 and 2013 in which parents sought accommodations on constitutional grounds from state education or local agency requirements. ${ }^{325}$

Table 2: Decisional Outcomes for Plaintiffs on Religious Accommodation Claims in K-12 Educational Settings in United States Courts of Appeal during Sherbert v. Verner (1963-1990) and Employment Division v. Smith (19902013) Eras

\begin{tabular}{|l|l|l|l|l|l|}
\hline Case Type & \multicolumn{2}{|l|}{ Sherbert v. Verner Era } & \multicolumn{2}{|l|}{$\begin{array}{l}\text { Employment Division } \\
\text {. Smith Era }\end{array}$} & Total \\
\hline & Won & Lost & Won & Lost & \\
\hline $\begin{array}{l}\text { Free } \\
\text { Exercise }\end{array}$ & 2 & 19 & 2 & 24 & 47 \\
\hline $\begin{array}{l}\text { Due } \\
\text { Process }\end{array}$ & 0 & 4 & 3 & 15 & 22 \\
\hline $\begin{array}{l}\text { Equal } \\
\text { Protection }\end{array}$ & 0 & 8 & 1 & 13 & 22 \\
\hline Hybrid & 0 & 0 & 0 & 7 & 7 \\
\hline Total & 2 & 31 & 6 & 59 & 98 \\
\hline
\end{tabular}


Table 2 reveals that, on all claims (Free Exercise, Due Process, Equal Protection or hybrid theories) during the Sherbert era, parents prevailed on only two claims while losing on thirty-one. ${ }^{326}$ This means that on all claims during that time period plaintiffs prevailed about $6.1 \%$ of the time. Further, during the Sherbert era, Free Exercise claimants prevailed about $9.5 \%$ of the time. During this period no Due Process, Equal Protection or hybrid religious liberty claimant prevailed on any claim.

On all claims during the Smith era, parents prevailed on six claims, while losing on fifty-nine. Therefore, these claimants prevailed only about $9.2 \%$ of the time. During the Smith era, Free Exercise and Due Process claimants each succeeded only about $7.7 \%$ of the time. During the Smith era, Equal Protection claimants succeeded in $7.1 \%$ of their efforts. No hybrid claimant succeeded against school districts during the Smith era. When the Sherbert and Smith outcomes are combined, claimants succeeded on eight of ninety-eight claims or $8.2 \%$ of their claims.

A 2 (won-lost) x 2 (Sherbert v. Verner/Employment Division v. Smith era) test of independence was performed to determine whether plaintiffs' success rate on all claims during the Sherbert era differed from the claims made during the Smith era. ${ }^{327}$ This difference was not statistically significant. ${ }^{328}$ Similarly, no statistical difference in success rates was found between the Sherbert and Smith eras for Free Exercise claims. ${ }^{329}$ Although the differences in success frequency between for the two eras for the Due Processand Equal Protectionare not meaningful in any practical way, their statistical significance could not be formally calculated. ${ }^{330},{ }^{331}$ Due Process, ${ }^{332}$ or Equal Protection ${ }^{333}$ claims.

This data reveals, unequivocally, that Congress and the eighteen states so far having adopted RFRAs were mistaken when they incorporated Sherbert and Yoder standards into their enactments because they were doomed to fail, at least if the school case outcomes can be generalized to other settings. Indeed, there is every indication that they can. This is evident from the work done by James E. Ryan in the early

326. These outcomes do not equal the number of decisions in the Appendix because the courts decided multiple claims in the same case. See infra $\mathrm{pp} .79-82$.

327. A test of independence is a hypothesis-testing procedure that examines whether the distribution of frequencies over the categories of one nominal variable are unrelated to the distribution of frequencies over the categories of another nominal variable. By convention a difference is considered significant if the probability of the observed difference in frequency is less than or equal to .05 , This is stated as $p \leq .05$. See generally ARTHUR ARON \& Elaine N. ARON, STATISTICS FOR PSYCHOLOGY 507-42 (Leah Jewell et al. 3d ed. 2003). A nominal variable is one with values which are names rather than numbers. Id. at 4.

328. A Fisher's exact test of independence $[p=714]$ revealed no relationship between era and decisional status.

329. A Fisher's exact test of independence $[p=382]$ revealed no relationship between era and decisional outcome for Free Exercise claims $\chi^{2}=0.880, \mathrm{df}=1, \mathrm{p} .>.05$.

330. This is because the Fisher's statistic requires that each cell in the calculation contain an integer between one and five hundred.

331. $\chi^{2}=0.880, \mathrm{df}=1, \mathrm{p} .>.05$.

332. $\chi^{2}=0.146, \mathrm{df}=1, \mathrm{p} .>.05$.

333. $\chi^{2}=0.823, \mathrm{df}=1, \mathrm{p} .>.05$. 
1990s, ${ }^{334}$ and Professor Lund ${ }^{335}$ and Wright ${ }^{336}$ discussed above. ${ }^{337}$

In 1992 Professor Ryan asserted that, despite the uproar over the Supreme Court's Smith decision and the enactment of a legislative remedy to overcome Smith, things would be unlikely to change much to advance religious liberty. ${ }^{338} \mathrm{He}$ did this by examining the ninety-seven federal appellate decisions involving Free Exercise claims issued in the ten-year period immediately preceding Smith. ${ }^{339}$ His study revealed that only one or two federal appellate decisions would have turned out differently under Smith than they did under the Sherbert test. ${ }^{340}$ This led Ryan to predict that legislative efforts to restore Free Exercise rights to the Sherbert standard would be ineffective in achieving the goals religionists and their supporters sought. ${ }^{341}$ In the twenty-plus year since Ryan wrote his article, his insights have turned out to be prescient.

This study is both narrower and broader than Ryan's. It is narrower in that it includes only cases involving $\mathrm{K}-12$ public education disputes reaching federal appellate courts, while his study examined claims from every walk of governmental activity. Although the focus in this study may limit the generality of its conclusions, it has the advantage of narrowing the discussion and developing a meaningful understanding of the issues that arise in this highly regulated area of state control. Moreover, unlike most religious liberty disputes, claims arising in public education implicate both Free Exerciseand parental Due Process interests, ${ }^{342}$ although in earlier cases of this type the Supreme Court evaluated such claims solely based on the parents' Due Process interest in controlling the upbringing of their child. ${ }^{343}$ This alone warrants separate treatment. This study is broader than Ryan's in that it covers about an eighteen-year period preceding Smith, whereas Ryan's covered a ten-year period. ${ }^{344}$ Moreover, this study examines decisions issued during the Smith era, from 1990 through 2013, a database unavailable to Professor Ryan when he wrote his article.

Three conclusions seem inescapable: (1) by RFRAs directing judges to apply Sherbert standards, legislatures selected criteria which had unequivocally failed to promote religious liberty during the preceding thirty years; (2) this virtually guaranteed RFRAs' failure going forward; and (3) neither the original nor later federal legislative enactments, or their state counterparts, have succeeded in achieving the RFRAs' legislative goal of expanding religious liberty.

334. Ryan, supra note 13.

335. See discussion supra notes 220-248 and accompanying text.

336. See discussion supra notes 248-260 and accompanying text.

337. See discussion supra notes 220-260 and accompanying text.

338. Ryan, supra note 13 , at 1413-17, 1439-41, 1445-49.

339. See id. at 1416-34.

340. See id. at 1414, 1433-34.

341. See id. at $1437-41$.

342. See, e.g., Wisconsin v. Yoder, 406 U.S. 205, 218 (1972). Recall that the Court in Employment Division v. Smith, 494 U.S. 872 (1990) treated Yoder as a hybrid case in which Free Exercise and Due Process interests joined to sustain the result. See supra text accompanying notes 23-45.

343. See, e.g., Meyer v. Neb., 262 U.S. 390 (1923); Pierce v. Soc'y of Sisters of the Holy Names of Jesus \& Mary, 268 U.S. 510 (1925).

344. See Ryan, supra note 13 , at 1412. 
Although there is probably little which can be done about influencing constitutional interpretation at the United States and State Supreme Court levels, the scholarly research discussed above and the current investigation have much to say about how to draft $\mathrm{K}-12$ religious freedom statutes if they are to become effective tools for preserving religious liberty. How these lessons might be applied is taken up in the next Part.

\section{ELEMENTS OF A MOdEL StatuTE}

\section{A. General Considerations in Drafting a Model Statute}

Although the legislative reaction to the Supreme Court's Smith decision was intense, ${ }^{345}$ it should not have taken accommodations advocates by surprise. This is because, during the decade leading up to Smith, there were many signs that the Supreme Court would avoid applying Sherbert strict scrutiny to religious accommodation disputes. ${ }^{346}$ This trend, culminating in Smith, moved the Free Exercise Clause from being the protector of individual religious conscience and the autonomy of religious groups from state intrusions to being the protector of mere neutrality. ${ }^{347}$ The losses suffered by religious advocates were attributable to the fact that plaintiffs had, in the Courts' view, failed to "press[] a serious enough religious interest," failed to show "a substantial enough burden on their religious exercise," or

345. See discussion supra notes 20-21 and accompanying text (federal RFRA) and notes 220-238 and accompanying text (state RFRAs).

346. See, e.g., United States v. Lee, 455 U.S. 252, 259, 261-262 (1982) (denying a free exercise exemption from social security taxes for Amish employer on the ground that "maintaining a sound tax system was of such a high order" as to overcome religious objections to paying the tax); Goldman v. Weinberger, 475 U.S. 503 (1986) (holding that a military officer does not have a free exercise right to wear his yarmulke while on duty, since requirements for military discipline and uniformity outweigh any countervailing religious interests); Bowen v. Roy, 476 U.S. 693 (1986) (rejecting Native American parent's free exercise claim that requiring his child to obtain a social security number would impair her spiritual development until she reached age sixteen ); O'Lone v. Estate of Shabzz, 482 U.S. 342 (1987) (dismissing free exercise claim of Islamic prisoners precluded from engaging in collective Friday worship on ground that, in light of the state's penological interest, a special burden should not be placed on prison officials to prove that no reasonable method existed to accommodate prisoners' religious practices, and that prison officals acted in a reasonable manner); Lyng v. Nw. Indian Cemetery Prot. Ass'n., 485 U.S. 439 (1988) (holding that, while government's actions will interfere with their religious practice, constructing a road through a section of National Forest that has traditionally been regarded as sacred area by three American Indian tribes does not violate the tribes' free exercise rights); Jimmy Swaggart Ministries v. Bd. of Equalization of California, 493 U.S. 378 (1990) (holding that the levy of a state sales and use tax on the distribution of religious materials is not a prior restraint on the free exercise of religion, and that the tax did not place a substantial burden on the freedom of the organization to practice its ministry).

347. See WITTE \& NiCHOLS, supra note 2, at 158 (arguing that during the 1980s the Supreme Court "had written out of the Free Exercise Clause the multiple principles that had informed the Court's earlier free exercise opinions"-such as its solicitude for liberty of conscience and equality of religious faiths-and blunted its previously nuanced interpretations of the Free Exercise Clause by converting it to one of "simple neturality"). Professors Witte and Nichols suggest that the failure to discern the erosion of Sherbert $v$. Verner standards in the decade preceding Smith might be understandable since, in the late $1980 \mathrm{~s}$, the Supreme Court issued two decisions, Corporation of Presiding Bishop of Church of Latter-day Saints v. Amos, 483 U.S. 327 (1987) (upholding exemption of religious school from civil rights statutes prohibiting religious discrimination in employment where employee had lapsed from his faith), and Frazee v. Illinois Department of Employment Security, 489 U.S. 829 (1989) (holding unconstitutional the state's denial of unemployment benefits to claimant who refused to accept job that might require him to work on Sundays), in which cases the Court continued to apply the strict scrutiny standards introduced in Sherbert. id. at 159. 
failed to establish "that their interest outweigh[ed] the government's.",348

Religionists' claim failures derived principally from the application of two analytic frameworks: (1) judicial balancing of the constitutional claim against the governmental interest at stake, often measured by the centrality of the governmental power that is threatened, and (2) applying the three familiar standards of review used in civil rights litigation, that is, rational basis low-level scrutiny, ${ }^{349}$ heightenedintermediate scrutiny, ${ }^{350}$ or high-level strict scrutiny, ${ }^{351}$ in assessing the claim's merit.

Given the limited constitutional remedies available to plaintiffs in Smith's wake, statutory remedies emerged as the balm of choice. ${ }^{352}$ There is great irony in the course of religious liberty during the last half-century: the Free Exercise Clause now offers the "least promising pathway to relief" ${ }^{353}$ since those claims benefit from the lowest scrutiny available in the constitutional continuum. ${ }^{354}$

Each of the eighteen state RFRAs contain weaknesses derived from the federal RFRA, which must be overcome to create an effective statute protecting religious liberty in educational settings. These deficiencies have enabled courts to countermand what history and state legislative intent show to be the goal of protecting religious exercise from government infringement. ${ }^{355}$ The two principal ways in which courts have created obstacles to attainment of these legislative goals are: (1) defining government action which substantially burdens religious exercise so

348. See id. at 133; see also Daniel Kazhdan, Comment, How Jewish Laws of Resistance Can Aid Religious Freedom Laws, 100 CAL. L. REV. 1069 (2012) (arguing that courts do not sufficiently consider the perspective of the burdened religion in First Amendment, RFRA, and the RLUIPA claims and recommending criteria to assess the severity of the burden). Notably, the cases cited throughout this article rarely reached the issue of narrow tailoring. But see supra pp. 26-28(discussing Gonzales v. O Centro Espirita Beneficente Uniao Do Vegetal, 546 U.S. 418 (2006)(and supra pp. 22-23 (discussing Cheema v. Thompson, 67 F.3d 883, 885-86 (9th Cir. 1995).

349. See, e.g., Reynolds v. United States, 98 U.S. 145 (1879) (upholding a federal criminal statute crimininalizing polygamy, and dismissing the prisoner's free exercise claim that the statute violated his Mormon religious beliefs by asserting that, while beliefs could not be regulated, actions could); Emp't. Div, v. Smith, 494 U.S. 872 (1990) (holding that the denial of unemployment compensation benefits to Native American claimants discharged for sacramental use of the proscribed drug, peyote, did not violate the Free Exercise Clause).

350. See, e.g., Watchtower Bible \& Tract Soc'y of New York, Inc. v. Vill. of Stratton, 536 U.S. 150 (2002) (holding that ordinance requiring door-to-door solicitors and canvassers to obtain a permit containing one's name violates First Amendment Free Speech and Free Exercise rights in light of ordinance's breadth and government's failure to narrowly tailor the ordinance to its stated interest in preventing fraud, crime, and privacy invasion); Cantwell v. Connecticut, 310 U.S. 296 (1940) (holding that city licensing law, which required religious groups to procure a license to solicit in advance, but giving broad discretion to local administrators to deny such licenses, violated the Free Exercise Clause).

351. See, e.g., Sherbert v. Verner, 374 U.S. 398 (1963) (holding that state's denial of unemployment compensation to claimant discharged from job for refusing to work on the Sabbath violates the Free Exercise Clause); Cutter v. Wilkinson, 544 U.S. 709 (2005) (holding that RLUIPA, which applies strict scrutiny in land use and prisoner cases, does not violate the Establishment Clause).

352. See WITTE \& NICHOLS, supra note 2, at 160-62; see also id. at 163 (lamenting the Supreme Court's narrowing of Free Exercise rights as contrary to its root principles of "liberty of conscience, freedom of religious expression, and religious equality and pluralism," and arguing that, until the Court reverses course, "further free speech and statutory protections of religious liberty must be vigilantly pursued in the short term").

353. Id. at 139 (emphasis in original).

354. Id.

355. See Wright, supra note 206 , at 444 . 
narrowly that many plaintiffs with valid claims are denied relief ${ }^{356}$ and (2) incorporating elements of Smith neutrality, despite the fact that RFRA's were intended to overcome Smith's holding. ${ }^{357}$

Any legislative solution must address each of these features by curtailing executive and judicial power and particularizing parental rights in educational settings so that school officials know with relative certainty what religiously-based conduct is protected and what conduct is proscribed.

\section{B. Elements of the Statute}

\section{Naming the Statute}

Naming the statute "The Right to Religious Accommodations Education Act" or "The Religious Freedom in Education Act," or a similar title, would send a signal to educators and the judiciary that lawmakers are especially concerned with religious liberty in educational settings. If the overwhelming number of losses suffered by plaintiffs in K-12 religious accommodation disputes is due in part to legislatures' failing to signal their special concern with this area of governmental functioning, renaming the statute would move the focus from the general to the specific and encourage the executive and judicial branches to take the Act more seriously than they have under RFRAs.

\section{Statement of Legislative Findings and Purpose}

\section{(a) Legislative Findings}

Among its findings, the legislatures should state that: (1) prior RFRAs have been unsuccessful in adequately protecting students and parents from burdens on their religious exercise in $\mathrm{K}-12$ education in public, private secular, private nonsecular, and home-schooling settings; (2) laws and governmental actions which are facially neutral toward religion, as well as laws and governmental actions intended to interfere with religious exercise, have frequently unduly burdened the free exercise of religion by parents and children interfacing with $\mathrm{K}-12$ public educational agencies; (3) the narrow construction courts have given to religious burdens and the broad construction they have given to the state interests to justify regulating conduct which burdens religious exercise in K-12 educational settings are expressly rejected; (4) there is a need to lift the undue burdens on religious liberty confronted by students and their parents in $\mathrm{K}-12$ educational settings and ensure that such liberty will be protected; and (5) there is a need to reduce ambiguities embodied in general religious liberty enactments, such as the RFRAs, and make more concrete what rights it intends to protect in K-12 educational settings. ${ }^{358}$

356. Id. at 433-35 (showing how the "substantial burden" test is the most serious obstacle to plaintiffs' success under state RFRAs).

357. Id. at 435-38 (illustrating how, over time, state courts have applied Smith's neutrality principles "through the back door," despite clearly expressed legislative intent to reject the Smith standard).

358. The language in this paragraph is intended to overcome the paucity of findings typically found in state 


\section{(b) Legislative Purpose}

A statement should be made that the purpose of the Act is to: (1) ensure accommodation of religious exercise in public, private secular and nonsecular schools, and home-schooling settings when agencies implement public education requirements; (2) expand in K-12 settings, mandated religious accommodations given to religious adherents in $\mathrm{K}-12$ educational settings beyond current federal and state constitutional and statutory minima; (3) recognize in K-12 educational settings, genuinely felt acts of religious conscience in K-12 educational settings which do not fall within institutional religious practice; ${ }^{359}$ (4) define protected religious conduct within K-12 educational settings to include "any exercise of religion, whether or not compelled by, or central to, a system of religious belief;" 360 and (5) require that all laws the legislature has heretofore enacted or will hereafter enact which impact religious exercise in K-12 educational settings be construed so as to avoid the imposition of burdens upon the free exercise of religion as established by the Act, absent compelling health and safety justifications, or unless otherwise permitted under the Act. ${ }^{361}$

Although the statute could still require "sincerely held religious beliefs" as a threshold requirement for an accommodation, the burden of proving this would only be by a preponderance of the evidence. ${ }^{362}$

\section{Applicability of the Act}

\section{(a) General rule}

The Act should state that it would apply to any "State or local law or ordinance and the implementation of that law or ordinance," affecting directly or indirectly $\mathrm{K}$ 12 education. It would state that: ${ }^{363}$ "Any law enacted by the [legislature] after the effective date of this [A]ct" would be made "subject to this [A]ct unless the [legislature] expressly excludes that law from the Act's coverage "by specific

RFRAs and make clear what is often only implied in these laws. See Wright, supra note 239, at 431-32 (discussing this problem).

359. See, e.g., Thomas v. Review Bd. of Indiana Emp't Sec. Div., 450 U.S. 707, 714-15 (stating that it is not the role of the judiciary to determine whether a claimant's beliefs are consistent with the system of any religious denomination).

360. See Religious Land Use and Institutionalized Persons Act of 2000, 42 U.S.C. $\S 2000 \mathrm{cc}-5(7)(A), 42$ U.S.C. $\$ 2000 \mathrm{cc}$ (West) (2000).

361. This provision is intended to narrow judicial discretion in finding compelling educational justification for imposing religious burdens while allowing such exceptions as are contained in the Act.

362. This threshold showing has not usually posed a problem for religious adherents. See, e.g., Wis. v. Yoder, 406 U.S. 205 (1972); Emp't. Div., Dept. of Human Res. of Oregon v. Smith, 494 U.S. 872 (1990); but see, Friedman v. Clarkstown Cen, Sch. Dist., 75 F. App'x 815, 818-19 (2d Cir. 2003) (holding that because parent failed to show the relevant nexus between her religious beliefs and immunization, her son was not entitled to the exemption the statute afforded). See also, Caroline L. Kraus, Note, Religious Exemptions-the Applicability to Vegetarian Beliefs, 30 HOFSTRA L. REV. 197, 215-17 (2001) (stating that among the kinds of evidence relevant to a sincerity determination are: (1) whether a person acted inconsistently with his claimed belief;, (2) whether a person "materially gained" by masking a secular belief; "with a religious veneer", and (3) whether the asserted beliefs are connected to "the religion's history and size and historical existence.").

363. See 71 PA. STAT. ANN. $\S 2406$ (West 2002). This language is typical of state RFRAs. 
reference to this $[\mathrm{A}] \mathrm{ct} .{ }^{\text {"364 }}$ The Act would also apply to non-governmental agencies performing educational functions for educational agencies when such entities are acting under color of state law. ${ }^{365}$ Under the Act "[a]n individual or a church, association of churches or other religious order, body or institution which qualifies for exemption from taxation under section 501(c)(3) or (d) of the Internal Revenue Code of 1986" or any successor thereof would be protected from encroachments on their religious liberty as defined by the Act. ${ }^{366}$

\section{(b) Exceptions}

Despite the requirements contained in the immediately preceding paragraph (a), the Act would not apply to any of the following: (1) any criminal offense involving the illegal use of a controlled substance or drug on school premises which is graded as a felony or a misdemeanor; ${ }^{367}$ ( (2) any provision of the applicable motor vehicle laws which does any of the following: (a) requires the licensing of school motor vehicle operators in K-12 educational settings, (b) requires the registration or inspection of motor vehicles used in the transportation of students in K-12 educational settings, (c) "requires financial responsibility for motor vehicle accidents," including any minimum liability coverage under the applicable state law, (d) "protects the public from the unsafe operation of motor vehicles;"368 (3) any law "which requires physicians or professional nurses to be properly licensed in order to practice their profession;"369 (4) any provision of the state Public Safety or Welfare Codes, or similar provisions, "which prevents the endangerment of the health or safety of persons in facilities which are licensed or supervised" under state and local law; ${ }^{370}(5)$ any provision of state or local law which requires the safe construction or operation of schools or other buildings visited by members of the public; ${ }^{371}(6)$ any general provision of state or local law whose purpose is to prevent the endangerment of health and safety; ${ }^{372}$ and (7) any law which requires the reporting of child abuse

364. The quotedSee id. This language in this paragraph was derived from 71 PA. STAT. ANN. $\S 2406$ and is typical of state RFRAs.

365. There is a growing controversy over whether the federal RFRA's relief section applies as a defense in suits between private citizens. See, Shruti Chaganti, Note, Why the Religious Freedom Restoration Act Provides a Defense in Suits by Private Plaintiffs, 99 VA. L. REV. 343 (2013). This issue falls outside the scope of this article.

366. See, 71 PA. STAT. ANN. $§ 2403$ (defining a "person" protected by the statute to include such entities).

367. See id. $\$ 2406(b)(1)$. Conceivably an adherent wishing to obtain an exemption for the use of controlled substancesubstances or illegal drugs, as a sacrament, might invoke Gonzales v. O Centro Espirita Beneficente Uniao Do Vegetal 546 U.S. 418 (2006) discussed. See supra notes 187-98 and accompanying text. Although in rare cases such a claim might succeed, the health and safety preemption contained in the proposed law should adequately cover this circumstance. Moreover, as a practical matter, it is extremely unlike that whatever sacramental purpose a felony or misdemeanor graded drug might serve, use of such substances would not arise in K-12 educational settings since they are typically used, as in Gonzales, during religious services.

368. See 71 PA. STAT. ANN. $\$ 2406($ b)(2). This provision would not ordinarily apply to home-schooled students. However, where a home-school became a private school, as defined by state law, then such schools would be subject to the transportation requirement of this Act.

369. See id. $\$ 2406(\mathrm{~b})(3)$.

370. See id. $\$ 2406(\mathrm{~b})(4)$.

371. See id. $\$ 2406(\mathrm{~b})(5)$.

372. See id. $\$ 2406(\mathrm{~b})(6)$. 
and maltreatment or educational neglect of a child. ${ }^{373}$

\section{Targeting Religious Accommodations in K-12 Educational Settings}

Table 1 above is helpful in showing those conflict areas that require legislative redress. ${ }^{374}$ Since it is unlikely that these conflicts will abate any time soon, they are the most obvious targets for legislative reform. A potential legislative solution for each of these areas is discussed below.

\section{(a) Group Meetings and Religious Practices}

Perhaps the most obvious and least controversial target for the proposed statute would be permitting devotional activities in public schools. The Act would: (1) permit, as of right, students to participate in voluntary group devotional activities during non-instructional time before, during, ${ }^{375}$ and after school, ${ }^{376}$ but no student or public employee would be allowed to coerce another student to participate in the devotional activities; (2) require that no on-campus student devotional group could be led or directed by any public school employee, but public employees would be permitted to monitor such group activities for the purpose of ensuring student safety and good order, just as they are under the Equal Access Act (EAA); ${ }^{377}$ and (3) permit student participants to select their own leaders so that they are adherents to the group's faith, if that is the choice they make, despite non-discrimination provisions

373. Much of the language in this paragraph was drawn from 71 PA. STAT. ANN. $\S 2406$ (b). The provisions of the Act regarding transportation would not ordinarily apply to home-schooled students. However, where a home-school became a private school, as defined in state law, then such schools would be subject to the transportation requirement of the Act. See id. $\S 2406(\mathrm{~b})(7)$.

374. See Table 1 and supra note 359 and accompanying text.

375. Study halls and other quasi-instructional situations would have to be addressed by state legislatures. The safer course would simply be to treat them as academic periods since they are designed for that purpose, even though that purpose may not always be achieved.

376. Typically, this would occur just prior to or after normal school hours, or perhaps during recess periods, when no instruction or other curriculum-mandated activities are occurring. Such a rule should obtain for other groups with philosophical, social, or other common values which lead to their association.

377. See Equal Access Act, 20 U.S.C. $\$ \S 4071-4074(f)$ (1984). The EAA gives non-curriculum related groups access to public secondary schools during non-instructional time (before and after school) to engage in religious, political, and philosophical kinds of discussion. See id. $\S 4071$. EAA only applies to school districts which receive federal financial assistance. See id. $\S 4071$ (a). The law is triggered when a school district has created what the EAA terms a "limited open forum" by allowing one or more non-curriculum groups to meet on school premises for expressive purposes. See id. $\S 4071$ (a)-(b). The Supreme Court held in Board of Education of Westside Community Schools v. Mergens, 496 U.S. 226 (1999), that the EAA does not violate the Establishment Clause. Id. at 248-49. Notably, the EAA does not limit the First Amendment rights of individual students to come together voluntarily during the school day for religious expression on school grounds, as long as it is done in a non-disruptive manner. See Clark v. Dallas Indep. Sch. Dist., 806 F. Supp. 116 (N.D. Tex. 1992). In 2007, Texas adopted the Religious Viewpoints Antidiscrimination Act (RVAA), which tracks the EAA, but goes beyond it, since the RVAA applies to elementary as well as secondary schools and during the school day. See TEX. EDUC. CODE ANN. $\$ \S 25.151-25.156$ (West 2007). The issue in implementing the RVAA will be balancing religious expression and exercise with Establishment Clause concerns. See Argyrios Saccopoulos, Note, Analysis: The Religious Viewpoints Antidiscrimination Act, 14 TEX. J. C.L. \& C.R. 127, 135-41 (2008) (questioning constitutionality of the Act on the ground it enables students to use school property to subject classmates to unwanted sectarian and proselytizing prayer during student addresses, thereby creating coercive elements, among other reasons). 
otherwise applicable in the school district policy. ${ }^{378}$

Where students ask for the opportunity to participate in devotional activities of the kind described in (1)-(3) above, school officials would be obligated to furnish a room or rooms for such purpose, if such space is available, but school officials could require students to show written parental permission for such activity prior to granting consent for any student's participation in those activities. ${ }^{379}$ Despite this provision, school officials would be required to take steps to curtail any student activities which would cause disruption of their educational programs or physical harm to student, staff, or faculty, or involve the harassment of students based on their race, national origin, gender, gender identity or sexual orientation, religious affiliation, and any social or political beliefs to which those students might subscribe.

\section{(b) Curriculum Accommodations}

\section{(1) Instruction}

The goal in this section would be to enable the parents to direct the upbringing of their children consistent with their religious beliefs or consciences, while ensuring the state's interest in achieving the students' acquisition of mandated curriculum content is satisfied. The components of this provision would allow: (a) students, upon written authorization from a parent or guardian, to be excused from class attendance where the content, or manner of presentation of the content, is objectionable to the parent or guardian on the ground of religious conviction or conscience, but such excusal would not relieve the student from the responsibility of learning the facts and theory of such curriculum content, knowledge of which would be acquired through home instruction, on-line, or other means selected by the parent or guardian; (b) students whose parents elect to excuse them from particular class attendance under this provision would not be excused from demonstrating knowledge of the curriculum on the same basis as other students for purposes of acquiring course credit, or passing from grade-to-grade, but such students would not be required to endorse, approve, or declare agreement with any scientific theory, or endorse any practice which may be implicated by such theory, which is inconsistent with his or her religion or conscience; (c) the required curriculum accommodations would include but not be limited to: religious or spiritual practices depicted in reading series or literature assignments; history or social science courses depicting content

378. Such coherence of values in the associational selection process would apply as well to associations based upon political or social philosophies. See Hsu v. Roslyn Union Free Sch. Dist. No. 3, 85 F.3d 839, 858 (2d Cir. 1996) (holding that although the school district was entitled to have an open admissions policy for EAA sanctioned clubs, a religious group could apply restrictions to its president, vice president, and music coordinator), cert. denied, 519 U.S. 1040 (1996); Truth v. Kent Sch. Dist., 542 F.3d 634 (9th Cir. 2008), cert. denied, 129 S.Ct. 2866 (2009), overruled by Los Angeles Cnty., Cal. V. Humphries, 131 S.Ct. 447 (2010) (holding that requiring student religious group to have nondiscriminatory membership qualifications did not violate the group's religion or the EAA, which only protects speech-based restrictions on religious groups).

379. Since most public school students at the the elementary and secondary level are heavily scheduled and the time which expires between periods is short, this requirement should result in few difficulties. These provisions would more likely require administrative time during lunch hours and periods immediately before school commences. 
religiously objectionable to the parents; health curriculum, including human anatomy, human reproduction, sexuality, sexual practices, and contraception; computer and technology skills; ${ }^{380}$ acceptance of alternative life styles, including same sex marriage and related issues; evolution and creationism; AIDS awareness; mandatory community service; valedictory and other speeches by students; speech and drama classes; ${ }^{381}$ annual applications for religious accommodations; and religiously based holiday music.

\section{(2) Curriculum Delivery}

Educational agencies would be required to make available curriculum content and class assignments on-line as an instructional resource for private and homeschooled students.

Private or home-school teachers should be able to explain to the students what concepts are being taught in public schools, while explaining how those principles may be distinguished from students' religious precepts. In all but the most insular of religious communities, this should give religious adherents sufficient latitude in prescribing their faith-based beliefs to their children while allowing state secular goals to be achieved. Indeed, as a practical matter, parents and their agents will indoctrinate their children into their belief systems regardless of any conflicting secular values. Moreover, in this media- saturated world, it is nearly impossible to isolate students from exposure to worldly activities and knowledge of the kind to which religious adherents object. This compromise affords appropriate respect and dignity to religious believers while permitting the state to fulfill its pedagogical functions.

(3) Flag Salute and Pledge of Allegiance

A school district and its agents and employees would be forbidden from requiring any student to salute the American or state flag, or other governmental symbol, or otherwise engage in any other patriotic exercise, including reciting the Pledge of Allegiance to the United States, which conflicts with the student's religious convictions or conscience. In the same vein, students wishing to be excused from such participation would be afforded the right to either stand or sit quietly during the exercise without penalty or recrimination of any kind. ${ }^{382}$ This rule would not forbid

380. See Stark v. Indep. Sch. Dist. No. 640, 123 F.3d 1068 (8th Cir. 1997) (affording an accommodation, based on religious objections, to use of technology in school setting).

381. In a case originating in a post-secondary setting, one court ruled that a former student in a state university's actor training program raised sufficient factual questions to defeat the university's motion for summary judgment on her Free Exercise Claim. Axon-Flynn v. Johnson, 356 F.3d 1277 (10th Cir. 2004). The student, who followed the Mormon faith, had refused to use profanity in a class exercise, despite the fact the language was contained in a script, because it forced her to violate her religious beliefs. Id. at 1281-83. The issues raised were: (1) whether strict script adherence imposed on the student was part of a neutral program of general applicability under Smith, or whether it was a pretext for religious discrimination and (2) if the program was neutral and generally applicable, whether the case fell into Smith's hybrid or individualized-exemption exceptions. See $i d$. at 1293-99. The fact question arose because exemptions from class requirements had previously been granted for non-secular reasons. See id. at 1298-99.

382. This rule would be easy to implement, involve minimal administrative time, and comports with 
the school from teaching about the history or policy rationale in the adoption of such practices, or prevent any school from adopting these or other patriotic exercises consistent with the students' protected First Amendment rights.

\section{(4) Dress and Grooming Rules}

Students would neither be prevented from wearing nor required to wear any religious garb or symbols where that choice results from the student's genuinely held religious beliefs, so long as it does not disrupt school operations, interfere with the rights of others, or pose a material threat to the student's health and safety or that of others. $^{383}$

\section{(5) Scheduling of Classes and Release Time}

Publically enrolled students would be entitled to be released from mandatory public school attendance for the purpose of receiving instruction at a private secular, nonsecular, or home-school not earlier than one hour prior to the end of the scheduled academic instructional day, nor more than one time in any school week; but this accommodation would not relieve the early-released student from fulfilling the same course requirements as other publically enrolled students. ${ }^{384}$ Where the appropriate missed work could be presented to parents through study sheets or extra-help classes or other suitable means, consistent with district practices, schools would be obligated to furnish these materials to the parents. Moreover, such support should be given to release-time students on an equal basis to that received by other students getting the same for non-religion based reasons.

No school district would be required to undertake any transportation expense to effectuate a student's early release program. The student would be permitted to be absent from school on mandatory days of religious obligation.

\section{(6) Compulsory Vaccination Programs}

Unlike many areas of contention between certain religious adherents and state educational agencies, excusal from compulsory vaccination programs gives rise to a

established case law.

383. See Menora v. Illinois High Sch. Ass'n, 683 F.2d 1030, 1034 (7th Cir. 1982); Cheema v. Thompson, 67 F.3d 883 (9th Cir. 1995). Menora is an excellent example of a thoughtful treatment to this kind of problem. There, the wearing of bobby pins to secure a religious head covering posed a safety threat. Menora, 683 F.2d at 1032-33. The circuit court returned the case to the district court to determine if a less dangerous alternative was available to secure the headgear. Id. at 1035. Presumably, a piece of tape would have allowed the accommodation without the risk to injury to someone's head or eyes and allow the students to satisfy the commands of their religion. In the same vein, see Cheema v. Thompson, 67 F.3d 883, 884-86 (9th Cir. 1995). There, the court's nuanced approach in addressing the students' religious needs to wear kirpans and the school's safety objective led to a similar outcome.

384. The duration and frequency of such release time is beyond the scope of this article. This should be a legislative determination following fact finding. The use of one hour, one time per week is just illustrative; it does not necessarily strike the right balance between accommodation and fulfilling the agency's educational mission. In any case, make-up work could be provided and the content covered on the district's web-site as a matter of course. 
truly compelling state interest. The failure to inoculate students from serious diseases poses substantial risk to the exempted students and other persons with whom they are educated. Unless the student could show he would suffer serious health risks by virtue of inoculation, which risk would be substantiated by the school's physician, no accommodation to such request should be granted. ${ }^{385}$ Where such accommodations are granted, the public school's physician would determine, in consultation with school officials, how instruction should be received by the student, based on the health risk factors to others and the pedagogical needs of the student. an setting thatproviders' needs

\section{(7) Private and Home Schooled Students}

\section{(a) Academic Programming and Privately Educated Students}

The Act should state what rights privately educated pupils enjoy. This would include, at minimum: (1) recognizing private secular, private nonsecular, and homeschooling programs as acceptable alternatives to public schooling, where they promote defined state educational standards; (2) ensuring that permitted alternative education includes $\mathrm{K}-12$, which is consistent with state compulsory attendance age constitutional or statutory requirements; (3) granting course credit, even for courses infused with religious teaching, so long as the secular content of the applicable course covers curricular requirements for that subject; ${ }^{386}$ (4) permitting students enrolled in a private secular, nonsecular, or home-school programs to enroll in any course offered by a public secondary school on the same basis as publicly enrolled students, but such privately enrolled secular, nonsecular, or home-schooled students would be required to show they have satisfied any course prerequisites for such enrollment on the same basis as publically enrolled students; (5) allowing students enrolled in the alternative educational program to participate in interscholastic and intrascholastic programs on the same basis as public enrolled students; (6) forbidding a public school or state educational agency from preventing students enrolled in private secular, nonsecular, or home-school programs from thereafter enrolling in public schools and receiving transfer credit for their secular studies undertaken at such secular, nonsecular, or home schools, but such private secular, nonsecular, or home-school

385. See, e.g., Allan J. Jacobs, Do Belief Exemptions to Compulsory Vaccination Programs Violate the Fourteenth Amendment?, 42 U. MEM. L. REV. 73 (2011) (arguing that based on scientific evidence, non-medical exemptions from vaccinations jeopardize the health gains achieved by state mandated vaccinations for communicable diseases, and that religious exemptions violate the Equal Protection and Due Process rights of children who do not have an exemption, since they are compelled by state laws to attend school and be exposed to the risk of communicable disease); John D. Lantos et al., Why We Should Eliminate Personal Belief Exemptions to Vaccine Mandates, 37 J. HEALTH POL. POL'Y \& L. 131 (2012) (arguing that personal belief exemptions from immunization requirements are unjust based on scientific evidence that failing to immunize puts exempt students and other students at risk for potentially dangerous diseases); Elizabeth J. Chen, Note, Equal Protection: Why the HPV Vaccine Should Be Mandated for Both Boys and Girls, 38 WASH. U. J.L. \& POL'Y. 289 (2012) (supporting HPV vaccination mandates for boys and girls and arguing for gender neutral policies as a more effective means of reducing incidents of HPV-related cancers).

386. Governmental entanglement could be avoided by simply evaluating students' progress on assessments prepared by the school district in core educational areas and setting standards equal to those required in public settings for granting course credit. 
students could be required to take academic examinations or other assessments covering the content of the courses for which they wish to receive credit, so long they are administered on an equal basis to students transferring from secular, nonsecular or home school settings; ${ }^{387}$ and (7) requiring students attending private and homeschool programs to pay for their educationally related transportation expenses, but those students could not be excluded from transportation furnished by the school district in which they reside when similar transportation, or reimbursement for transportation expenses, is given to similarly situated privately schooled or homeschooled students who participate in private education for secular reasons.

\section{(b) Academic Monitoring and Privately Educated Students}

All parents would have the right to elect home-schooling as an alternative for their children of compulsory attendance age, but conferral of this right would not prevent educational agencies from reasonably monitoring, by the least intrusive means, the educational attainment of home-schooled students to ensure they are receiving the minimum education required by the state. ${ }^{388}$

\section{(c) Interscholastic and Intramural Athletics and Privately Educated Students}

No student who is enrolled in a private secular, nonsecular or home-schooling program could be prevented from participation in interscholastic or intramural athletic programs in the school district in which he resides so long as that student is otherwise qualified to participate on that team or program.

No private secular or non-secular school could be prevented from joining an athletic league on account of its status as a private secular or non-secular school, so long as such school meets all other criteria reasonably necessary to ensure fair competition within such league. ${ }^{389}$

\section{Public Employees Exercising the Right to Direct the Upbringing of their Children}

No applicant or employee could be denied any employment opportunity or suffer any workplace discrimination on account of that applicant or employee having enrolled or intending to enroll his or her child in a private secular or nonsecular school

387. This would legislatively overrule cases like Murphy v. State of Arkansas, 852 F.2d 1039, 1043-44 (8th Cir. 1988), where a distinction was made between home schooled and privately schooled pupils in granting transfer credit upon return to the public school setting. See id.

388. Quarterly evaluations at school or at home, as decided by the parents, could be part of any such program. This would allow for progress reports which correspond to the issuance of report cards and permit adjustments to the students' instructional program where needed, or, in extreme cases, removal from the alternative program.

389. Typically, criteria such as the size of the high school and prohibiting high-pressure recruiting tactics apply. See, e.g., Brentwood Academy v. Tennessee Secondary Sch. Athletic Ass'n., 531 U.S. 288 (2001) (upholding sanctions against private academy for recruiting violations and rejecting claim that athletic association's rule violated free speech provisions of First Amendment). 
or home schooling alternative.

\section{Civil Actions}

Any statutory scheme that tries to protect religious liberty in K-12 educational settings must contemplate a range of issues typically confronted during the litigation process. They must address, at least, jurisdiction, notice of claim, pleading, claims and defenses, limitation periods, remedies, including awards of fees and costs. Each of these is discussed in turn.

\section{Jurisdiction}

A person alleging a violation of the Act by an educational agency would be entitled to bring an action in the state superior or equivalent court of general jurisdiction, where subject matter jurisdiction would exist and venue would lie in accord with the applicable state rules. However, where the defendant is the state educational agency and the agency is located in excess of fifty miles from the school district where the claimant resides, the claimant would be permitted to file the claim in the closest court of competent jurisdiction to the residence of the claimant.

\section{Notice}

A person would not be required to file a notice of claim, or otherwise give notice of intent to bring suit, as a condition precedent to the bringing of a lawsuit where the claimant alleges that an educational agency has placed a religious burden on the claimant not permitted under this Act. The failure to give such notice though could be a factor in a court's limiting an award of compensatory or exemplary damages pursuant to this Act.

\section{Pleading}

An actionable claim pursuant to this Act could be stated where: (a) the person's free exercise of religion in a K-12 educational setting, as set forth in this Act, has been or is about to be burdened, interfered with, restricted, or limited by an exercise of the agency's governmental authority; ${ }^{390}$ (b) the claimant describes the act or refusal to act which has burdened, or will burden the person's free exercise of religion, with enough specificity for the educational agency to understand the nature of the claim and the time frame in which it arose, however, where these requirements are not satisfied, the right to replead would be granted as a matter of right where it appears that the requirements of the Act may have been violated; and (3) the claimant states the manner in which the exercise of the governmental authority burdens,

390. This language is intended to overcome the tendency in the RFRA decisions to narrow what are considered burdens on religious exercise and therefore minimize the range of protected religious practices covered under the RFRAs. See, Lund, supra note 1, at 484-89 and discussion supra notes 220-248 and accompanying text; Wright, supra note 206, at 433-35 and discussion supra notes 248-260 and accompanying text 
interferes with, restricts, or limits the person's free exercise of religion.

\section{Burden of Proof}

Claimants would be required to show a burden on their religious exercise under the Act by a preponderance of the credible evidence. No heightened pleading requirement could be imposed on the claimant at any stage of the proceeding. Upon a claimant pleading a cause which satisfies the requirements set forth above, the defendant would be required to allege in its answer a compelling health and safety reason for denying the accommodation asked for by the claimant in order to prevail in its defense, unless an exception contained in the Act applied.

\section{Rights Not Limited by the Act}

The rights described in this Act would not limit the right of a person whose religious liberty is burdened by a K-12 educational agency to assert a claim under any state RFRA or other statute previously or later enacted, insofar as they may be applicable to the facts of the case unless such later Act specifically limited the provisions of this Act. The Act would be construed to supplement, not supplant, any other remedies available to a claimant.

\section{Claim or Defense}

A person whose free exercise of religion has been burdened, or likely will be burdened, in violation of the Act may assert that violation against an educational agency as a claim or defense in any judicial or administrative proceeding.

\section{Mandatory Settlement Conference}

Within 30 days following service of the complaint upon the educational agency, the agency would be required to conduct a settlement conference at the school district in which the claimant resides. Each party would be entitled to be accompanied by its attorney and required to participate. The agency would be required to give at least 10 days written notice to the claimant(s) of its intent to hold the conference, and offer alternative dates and times at which the conference could be held. Where the school district fails to make a good faith attempt to conduct the conference within the specified time, the claimant would be allowed to proceed with prosecuting the claim and the requirement for participation in a settlement conference would be deemed waived by the educational agency.

At the conference, all parties would be mandated to explain the nature of their positions and the reasons therefor, but none of the information received by any party during the conference would be admissible in evidence or in any later judicial or administrative proceeding. The fact of holding the settlement conference and the failure to reach an agreement at the conference would not be admissible in support of a claim or defense in any later judicial or administrative proceeding. 
8. Limitations

The state statute of limitations in civil rights proceedings would apply under the Act but that period could not be less than one year.

\section{Remedies}

If a person asserts a claim or defense in accordance with this Act and proves, by a preponderance of the evidence, that the person's free exercise of religion has been burdened, or likely will be burdened in violation of the Act, a court would be authorized to award the person such declaratory or injunctive relief as may be appropriate. Courts could award compensatory monetary or exemplary damages for a violation of the Act, but, in the case of exemplary relief, such damages could be awarded only if the court found that the actions of the educational agency were malicious, dilatory, obdurate, or vexatious. A prevailing party would be entitled to an award of reasonable attorneys' fees. In granting an award of such fees, the Court shall be required to follow the criteria set forth in 42 U.S.C. $\$ 1988$, which would be incorporated by reference into this Act. ${ }^{391}$

\section{Publication Required}

The state educational agency would be required to write a plain language version of the statute, which would be produced and distributed to all local educational agencies throughout the state. The statute and its plain language version would be required to be displayed prominently on bulletin boards in each school under the school district's auspices and posted on the agency's web-site. The statute and plain language version would be included in the agency's student handbook, and be explained to all teachers and non-certificated staff, at least annually, prior to the commencement of each school year and to all students upon their commencement of the school year, not later than the first two weeks following the start of the school year.

The foregoing provisions should offer adequate protection for K-12 students in exercising their religious rights, and should overcome the deficiencies in legislative RFRA drafting and judicial failures to apply RFRAs as they were intended to be applied. The specificity of the Act, along with its notice provisions and its removal of procedural obstacles, should go a long way in solving this seemingly intractable source of conflict. The Act's provisions respecting injunctive and declaratory relief, damages, fees, and costs, implemented as they are in other civil rights conflicts, should result in school officials being more amenable to early resolution of these disputes. The Act would allow educational agencies to achieve their important educational mission while accommodating the religious needs of students and their families. 


\section{SUMMARY AND CONCLUSION}

The Religious Freedom Restoration Acts (RFRAs), passed by Congress in 1993 and by eighteen states to date after the federal enactment, were intended to overcome the Supreme Court's 1990 decision in Smith. Smith applied to Free Exercise claims low-level rational basis scrutiny to neutral laws of generally applicability even when their effects burdened religious exercise. Smith effectively overruled Sherbert, which required states to show that a law that substantially burdens religious exercise is justified by a compelling state interest that is narrowly tailored to achieve that end. The purpose of the RFRAs was to return Free Exercise protections to what legislators considered to be the halcyon days of the post-Sherbert pre-Smith era.

This article shows that the assumptions underlying the RFRAs were erroneous, and resulted in a substantial failure in achieving legislators' goals both within and without K-12 education. This article did so by building upon the research performed by Ryan, Lund, Witte, Jr., Nichols and James W. Wright. This study revealed that:

1. Congress and the enacting state legislatures failed to examine judicial decisions under Sherbert before adopting RFRA standards. Under Sherbert (1963-1990) and after Smith (1990-2013), the success rate of plaintiffs during each era did not differ statistically from one another, either when all claims were aggregated (6.1\% v. 9.2\%), or when Free Exercise claims were examined separately. No meaningful differences in success rates for the two eras occurred when claims were asserted under Due Process, Equal Protection, or hybrid theories. By adopting standards that had already failed, legislators essentially guaranteed the RFRAs would fail as well.

2. The legislatures did not make findings as to which activities were more likely to result in conflict with persons wishing to exercise religious freedom and legislate in those areas. This perpetuated conflict which continues today.

3. The legislatures passed laws which: (a) did not distinguish state interests merely serving a governmental purpose from those that were essential to fulfilling educational agencies' core functions; (b) did not point with particularity to the specific protections afforded religious adherents; and (c) used language which focused on legal technicalities, such as "substantial burdens" on religion and the "compelling state interest test," which are largely bereft of meaning outside of particular agency interests. Thus, judges had limited guidance for determining what legislatures hoped to accomplish, and were vested with unwarranted discretion in determining the reach of the RFRAs.

This article proposes elements of a model statute directed at K-12 educational settings to overcome RFRA deficiencies. The proposed law contains a statement of legislative findings and purpose, and describes protected areas of religious exercise. These are: group meetings and religious exercise, accommodations in curriculum and instructional delivery, flag salutes and the Pledge of Allegiance, dress and grooming rules, class schedules and release-time programs, student health and safety, the rights of private and home-schooled students (including academic programming, academic monitoring, interscholastic and intermural athletics), public educational employees' right to direct their children's religious education, and publication and dissemination 
of rights embodied in the law.

The Act covers as well issues that are likely to arise when the rights of students under the proposed Act have been violated and litigation ensues. This includes jurisdictional and notice of claim and claim and defense pleading requirements, statutes of limitations, and remedies for violations of the Act, including fees and costs.

This legislative proposal embodies principles which are intended to: (1) overcome, within Establishment Clause limits, the unfair burdens which religious believers have experienced; (2) allow educational agencies to perform their core pedagogical functions; (3) give express notice to educational agencies of what they are required to do and what conduct of theirs is proscribed; and (4) encourage religious tolerance.

\section{THE END}

Appendix: United States Courts of Appeal K-12 Religious Accommodations Decisions

\section{Data Base: 1963-2013}

1. Stein v. Oshinsky, 348 F.2d 999 (2d Cir. 1965). Cornwall v. State Bd. of Educ., 314 F.Supp. 340 (D. Md. 1969), aff'd 428 F.2d 471 (4th Cir. 1970).

2. Jackson v. Cal., 460 F.2d 282 (9th Cir. 1972).

3. Spence v. Bailey, 465 F.2d 797 (6th Cir. 1972).

4. Wright v. Houston Indep. Sch. Dist., 366 F.Supp. 1208 (S. D. Tex. 1972), aff'd 486 F.2d 137 (5th Cir. 1973).

5. Sapp v. Renfroe, 511 F.2d 172 (5th Cir. 1975).

6. Florey v. Sioux Falls Sch. Dist., 619 F.2d 1311 (8th Cir. 1980).

7. Walsh v. Louisiana High Sch. Athletic Ass'n, 616 F.2d 152 (5th Cir. 1980).

8. Fiedler v. Marumsco Christian Sch., 631 F.2d 1144 (4th Cir. 1980).

9. Brandon v. Bd. of Educ. of Guilderland Cent. Sch. Dist., 635 F.2d 971 (2d Cir. 1980).

10. Windsor Park Baptist Church v. Arkansas Activities Ass'n, 658 F.2d 618 (8th Cir. 1981).

11. Church of God (Worldwide, Texas Region) v. Amarillo Indep. Sch. Dist., 511 F. Supp. 613 (N.D. Tex. 1981), aff'd sub nom. Church of God (Worldwide Texas Region) v. Amarillo Ind. Sch. Dist., 670 F.2d 46 (5th Cir. 1982).

12. Menora v. Illinois High Sch. Ass'n, 683 F.2d 1030 (7th Cir. 1982).

13. Grove v. Mead Sch. Dist. No. 354, 753 F.2d 1528 (9th Cir. 1985).

14. Smith v. Bd. of Sch. Comm'rs of Mobile Cnty., 827 F.2d 684 (11th Cir. 1987).

15. Fellowship Baptist Church v. Benton, 815 F.2d 485 (8th Cir. 1987).

16. Griffin High Sch. v. Illinois High Sch. Ass'n, 822 F.2d 671 (7th Cir. 1987). 
17. Mozert v. Hawkins Cnty. Bd. of Educ., 827 F.2d 1058, cert. denied 484 U.S. 1066 (1988 (6th Cir. 1987).

18. Smith v. Bd. of Educ., N. Babylon Union Free Sch. Dist., 844 F.2d 90 (2d Cir. 1988).

19. Mason v. General Brown Cent. Sch. Dist., 851 F.2d 47 (2d Cir. 1988).

20. Murphy v. Ark., 852 F.2d 1039 (8th Cir. 1988).

21. New Life Baptist Church Acad. v. Town of E. Longmeadow, 885 F.2d 940 (1st Cir. 1989).

22. Vandiver v. Hardin Cnty. Bd. of Educ., 925 F.2d 927 (6th Cir. 1991).

23. Sherman v. Cmty. Consol. Sch. Dist.. 21 of Wheeling Twp., 980 F.2d 437 (7th Cir. 1992).

24. Kissinger v. Bd. of Trustees of Ohio State Univ., Coll. Of Veterinary Med., 5 F.3d 177 (6th Cir. 1993).

25. Fleischfresser v. Directors of Sch. Dist. 200, 15 F.3d 680 (7th Cir. 1994).

26. Brown v. Hot, Sexy and Safer Prods., Inc., 68 F.3d 525 (1st Cir. 1995), cert. denied, 116 S.Ct. 1044 (1996).

27. Immediato v. Rye Neck Sch. Dist., 73 F.3d 454 (2d Cir. 1996).

28. Hsu v. Roslyn Union Free Sch. Dist. No. 3, 85 F.3d 839 (2d2dCir. 1996).

29. Herndon v. Chapel Hill-Carrboro City Bd. of Educ., 89 F.3d 174 (4th Cir. 1996).

30. Bauchman v. W. High Sch., 132 F.3d 542 (10th Cir. 1997).

31. Peterson v. Minidoka Cnty. Sch. Dist. No. 331, 118 F.3d 1351, amended by 132 F.3d 1258 (9th Cir. 1997).

32. Swanson v. Guthrie Indep. Sch. Dist. No. I-L, 135 F.3d 694 (10th Cir. 1998).

33. Altman v. Bedford Cent. Sch. Dist., 245 F.3d 49 (2d Cir. 2001).

34. Littlefield v. Forney Indep. Sch. Dist., 268 F.3d 275 (5th Cir. 2001).

35. Leebaert v. Harrington, 332 F.3d 134 (2d Cir. 2003).

36. Barrow v. Greenville Indep. Sch. Dist., 332 F.3d 844 (5th Cir. 2003), rehearing and rehearing en banc denied, 75 Fed. App'x, 982, cert. denied, Smith v. Barrow, 540 U.S. 1005.).

37. Friedman v. Clarkstown Cent. Sch. Dist., 75 F. App'x 815 (2d Cir. 2003).

38. Gary S. v. Manchester Sch. Dist., 374 F.3d 15 (1st Cir. 2004).

39. Barrett v. Stuebenville City Sch., 388 F.3d 967 (6th Cir. 2004).

40. Wilkins v. Penns Grove-Carneys Point Reg'l Sch. Dist., 123 F. App'x 493 (3d Cir. 2005).

41. Blau v. Fort Thomas Pub. Sch. Dist., 401 F.3d 381 (6th Cir. 2005), opinion amended on denial of reh'g sub nom. Fields v. Palmdale Sch. Dist. (PSD), 447 F.3d 1187 (9th Cir. 2006).

42. Skoros v. City of New York, 437 F.3d 1 (2d Cir. 2006).

43. Grossman v. S. Shore Pub. Sch. Dist., 507 F.3d 1097 (7th Cir. 2007).

44. Parker v. Hurley, 514 F.3d 87 (1st Cir.), cert. denied, 555 U.S. 815 (2008).

45. Borden v. Sch. Dist. of Twp. of E. Brunswick, 523 F.3d 153 (3d Cir. 2008).

46. Jacobs v. Clark Cnty. Sch. Dist., 526 F.3d 419 (9th Cir. 2008).

47. Combs v. Homer-Ctr. Sch. Dist., 540 F.3d 231 (3d Cir. 2008). 
48. Corder v. Lewis Palmer Sch. Dist. No. 38, 566 F.3d 1219 (10th Cir. 2009).

49. Nurre v. Whitehead, 580 F.3d 1087 (9th Cir. 2009).

50. Busch v. Marple Newtown Sch. Dist., 567 F.3d 89 (3d Cir. 2009).

51. Incantalupo v. Lawrence Union Free Sch. Dist. No. 15, 380 F. App'x 59 (2d Cir. 2010).

52. Freedom From Religion Found. v. Hanover Sch. Dist., 626 F.3d 1 (1st Cir. 2010).

53. Workman v. Mingo Cnty. Bd. of Educ., 419 F. App'x 348 (4th Cir. 2011).

54. Nampa Classical Acad. v. Goesling, 447 F. App'x 776 (9th Cir. 2011).

55. Johnson v. Poway Unified Sch. Dist., 658 F.3d 954 (9th Cir. 2011).

56. Ward v. Polite, 667 F.3d 727 (5th Cir. 2012).

57. Doe ex rel. Doe v. Elmbrook Sch. Dist., 687 F.3d 840 (7th Cir. 2012)(en banc). 2012). Caviezel v. Great Neck Pub. Sch., 500 F. App'x 16 (2d Cir. 2012), cert. denied, 133 S. Ct. 1998 (2013).

58. D.L. ex rel. K.L. v. Baltimore Bd. of Sch. Comm'rs, 706 F.3d 256 (4th Cir. 2013).

59. Taylor v. Roswell Indep. Sch. Dist., 713 F.3d 25 (10th Cir. 2013). 